\title{
Transformation, partitioning and flow-deposit interactions during the run-out of megaflows
}

\author{
CLAUS FALLGATTER*, BEN KNELLER $\dagger$, PAULO S. G. PAIM* and JUAN P. MILANA \\ *Departamento de Geologia, PPGeo, Universidade do Vale do Rio dos Sinos - UNISINOS -, \\ Av. Unisinos, 950, Setor C02, São Leopoldo, RS, Brazil (E-mail: claus.fallgatter@gmail.com) \\ $\uparrow$ School of Geosciences, University of Aberdeen, Aberdeen AB24 3UE, UK \\ $\$ C O N I C E T$, Universidad Nacional de San Juan, San Juan, Argentina
}

Associate Editor - Peter Talling

\begin{abstract}
Four megabeds (I to IV) were recognized throughout the Cerro Bola inlier, a glacially influenced depositional area of the Carboniferous Paganzo Basin, south-western La Rioja Province, Argentina. Such anomalous thick beds are associated with the collapse of an unstable basin margin after periods of large meltwater discharge and sediment accumulation. Failure of these previously deposited sediments triggered mass flows and associated turbidity currents into the basin. Megabed I is up to $188 \mathrm{~m}$ thick and was deposited during a transgressive stage by re-sedimentation of ice-rafted debris. Also part of the transgressive stage, Megabeds II, III and IV are up to $9 \mathrm{~m}$ thick and are associated with a dropstone-free period of flooding. Megabeds were subdivided into three divisions ( 1 to 3 ) that represent a spectrum of flow properties and rheologies, indicative of a wide range of grain support mechanisms. These divisions are proposed as an idealized deposit that may or may not be completely present; the Cerro Bola megabeds thus display bipartite or tripartite organization, each division inferred to reflect a rheologically distinct phase of flow. Division 1 is a basal layer that consists of clast-supported and matrixsupported, pebble conglomerate, rarely followed by weak normally graded to ungraded, very coarse- to coarse-grained sandstone. This lower interval is interpreted to be the deposit of a concentrated density flow and is absent in bipartite megabeds. Division 2 is represented by a mud-rich sandstone matrix with dispersed granule to pebble-size crystalline and mudstone clasts. It also includes fragments of sandstone up to boulder size, as well as rafts of cohesive muddy material and wood fragments. Division 2 is interpreted as a result of debris-flow deposition. A debrite-related topography, resulting from the freezing of high yield strength material, captures and partially confines the succeeding upper division 3 , which fills the topographic lows and pinches out against topographic highs. Division 3 is rich in mudstone chips and consists of very coarse-grained, dirty sandstones grading upward to siltstones and mudstones. It is interpreted to be a deposit of a co-genetic turbidity current. Spectral gamma ray and petrographic analyses indicate that both debrite and co-genetic turbidite have high depositional mud content and are of similar composition. One of the megabeds is correlated with an initial slump-derived debris flow, which suggests that the mass flow becomes partitioned both at the top, generating a co-genetic turbidity current and, at the base, segregating into a concentrated density flow that seems to behave as a gravelly traction carpet.
\end{abstract}


Keywords Co-genetic turbidity current, concentrated density flow, debris flow, megabeds, related topography.

\section{INTRODUCTION}

Sediment gravity flows such as debris flows and turbidity currents represent important mechanisms for delivery of sediment into deep-water, transporting large amounts of material for long distances (Hampton et al., 1996; Piper et al., 1999; Talling et al., 2007). The ubiquitous occurrence of their deposits in many deep-water settings reinforces their importance. Subaqueous debris flows are regarded as part of a continuum between slumps and turbidity currents (Lowe, 1982; Mulder \& Alexander, 2001; Shanmugam, 2006), and are considered to be one of the mechanisms for generation of turbidity currents (Hampton, 1972; Hampton et al., 1996; Mohrig \& Marr, 2003; Felix \& Peakall, 2006). However, cohesive debris flows might also form by reconcentration of an initial turbidity current (Fisher, 1983; Haughton et al., 2009; Talling et al., 2010, 2012; Kane \& Pontén, 2012). The term debris flow is used here to describe a cohesive flow in which the concentration of sediment is high enough to suppress turbulence and therefore deposit its charge by en masse freezing, resulting in an ungraded and commonly chaotic fabric of different size clasts (Middleton \& Hampton, 1973; Lowe, 1982). Turbidity current is used to describe a flow that is noncohesive, in which grains are mainly kept in suspension by fluid turbulence with progressive layer by layer deposition. However, flows where grain interactions and hindered settling may be important additional mechanisms of particle support are termed high-density turbidity currents (Lowe, 1982), differing from low-density turbidity currents, which are dominated by fluid turbulence (Mulder \& Alexander, 2001).

However, some gravity flow deposits show evidence of more than one type of flow behaviour acting during the same depositional event, suggesting that they can operate together (e.g. Haughton et al., 2009; Manica, 2012). This class of deposits, called hybrid beds, shows vertical sequences of end-members that form couplets or triplets related to cohesive and non-cohesive flows - debris flows or mud-flows, and low to high-density turbidity currents, respectively. In this sense, the terms bipartite and tripartite are used here to express a situation where the flow becomes partitioned longitudinally and/or vertically, generating different depositional behaviours during the same event. In this study, bipartite megabeds are lacking the basal layer that is present in tripartite ones.

Deposits resulting from hybrid flows have been reported in a number of deep-water successions of different ages (Wood \& Smith, 1957; McCaffrey \& Kneller, 2001; Haughton et al., 2003, 2009; Kneller \& McCaffrey, 2003; Talling et al., 2004; Hodgson, 2009; Jackson et al., 2009; Pyles \& Jennette, 2009; Talling, 2013), and seem to be mostly related to distal basin-plain and basin margin settings (Talling et al., 2004; Haughton et al., 2009; Hodgson, 2009). Deposits that might be included in the broader class of hybrid event beds were previously described as slurry flows (Wood \& Smith, 1957; Lowe \& Guy, 2000), sandwich beds (McCaffrey \& Kneller, 2001), linked-debrites (Haughton et al., 2003) and co-genetic debrite-turbidite beds (Talling et al., 2004). These papers describe $\leq 2 \mathrm{~m}$ thick beds generated by hybrid flows. Similar facies in much thicker beds are usually named megabeds, and are seldom explicitly ascribed to hybrid events (although see Pauley, 1995; Talling, 2013). Large deposits produced by hybrid megaflows have been termed complex beds (Marjanac, 1996), composite megabeds (Reeder et al., 2000) or hybrid megabeds (Talling, 2013).

Megabeds have been described as seismites, megaturbidites, seismoturbidites, megabreccias or mass-transport deposits (MTD), even when it is apparent that more than one type of flow is involved (Rupke, 1972; Ricci Lucchi \& Valmori, 1980; Johns et al., 1981; Mutti et al., 1984; Bouma, 1987; Bourrouilh, 1987; Kleverlaan, 1987; Labaume et al., 1987; Souquet et al., 1987; Pauley, 1995; Payros et al., 1999). These authors commonly ascribed the megabeds to seismic triggering, while others (Cita et al., 1984; Marjanac, 1996; Rothwell \& Kähler, 1998; Reeder et al., 2000; Rothwell et al., 2000) ascribe them to sea-level lowstands. There is no generally accepted definition of the term 'megabed', but they are usually ascribed to deposits of exceptionally large-volume sediment gravity flows (megaflows), representing episodes of anomalous 
sedimentation that produce much thicker beds than those of the subjacent and suprajacent succession, and often represent what are inferred to be rheologically more complex events than those responsible for deposition of the surrounding rocks. Bouma (1987) suggested the use of the term 'megaturbidite' for layers that have internal properties that suggest they are the deposit of one single transport event, even if that event covers several depositional processes. The term megabed is used here in the same sense.

The deposits resulting from the cohesive component of the megabeds are commonly attributed to debris flows with high yield strength, which may lead to significant topography on their upper surfaces after (or at the point of) cessation of movement. Topography associated with large debris-flow deposits that influences the following sedimentary succession has been described in many deep marine settings (Cronin et al., 1998; Pickering \& Corregidor, 2005; Armitage et al., 2009; Jackson \& Johnson, 2009; Dykstra et al., 2011; Kneller et al., 2016). Some megabeds described in the literature are also associated with a debrite-related topography, and flow-deposit interactions at the interface between the debrite and the following turbidite (Kleverlaan, 1987; Labaume et al., 1987; Hodgson \& Pickering, 2008), although they do not explicitly refer to it as a possible combination of emplacement processes. In addition, laboratory experiments have demonstrated the potential for this topography to generate traps where succeeding deposits are encased (Brunt et al., 2004; Lamb et al., 2004, 2006). However, in contrast to these works, the Cerro Bola megabeds present evidence of interactions during one single flow.

Based on the above, the aims of this contribution are: (i) to document the importance of debrites with linked turbidites, a widely observed variant in the broader class of hybrid beds, largely neglected since the literature has become dominated by turbidites with linked debrites; (ii) to review the trend of megabeds from the 1980s to the present; (iii) to infer how debris flows may partition downcurrent to generate cogenetic flows, thus providing a clue to the behaviour of subaqueous debris flows; (iv) to suggest an origin for the clast-rich basal layer in tripartite megabeds which has only rarely been described; (v) to document flow-deposit interaction during a single megaflow event and the potential of debrite-related topography in partially confining (or ponding) the subsequent co-genetic flow; and (vi) to generate an associated facies tract model that may be useful to support well data descriptions and reduce subsurface uncertainties by prediction of facies variation away from the well-bore.

\section{GEOLOGICAL SETTING}

The Cerro Bola area is located in La Rioja Province, central western Argentina, and is part of the eastern Paganzo Basin. The Permo-Carboniferous Paganzo Basin occupies an area of $30000 \mathrm{~km}^{2}$, and represents one of the most extensive areas of late Palaeozoic glacially influenced deposits in the world (Azcuy et al., 1999). It was formed in a retro-arc position at the western margin of Gondwana, and experienced a series of glacial/deglacial episodes related to pulsed glaciation as the supercontinent moved over high latitudes (López-Gamundí et al., 1992). The Carboniferous glacial influence is recorded in the Paganzo Basin as cycles of glacial advance and retreat (Limarino et al., 2006). Ramos (1988) interpreted it as a retro-arc foreland basin based on tuffs sourced from a possible volcanic arc to the west, whereas Fernandez Sevesso \& Tankard (1995) describe it as a strikeslip basin. Fernandez Sevesso \& Tankard (1995) divided the basin into three supersequences (Guandacol, Tupe and Patquía) based on similarly named lithostratigraphic units. The first one, which includes the strata here described, is up to $2000 \mathrm{~m}$ thick and includes dropstone-bearing, thin-bedded turbidites and shales, indicating a proglacial depositional setting.

The Cerro Bola area, according to Dykstra et al. (2011), is a large, west-vergent, northsouth oriented, hanging wall anticline associated with a thrust fault. The thrust fault dips ca $24^{\circ}$ to the east and is related to the Late Cenozoic Pampean Range orogenic deformation (Zapata \& Allmendinger, 1996). The present day topography largely reflects the actively growing structure in which a Carboniferous to Triassic succession is exposed. The Cerro Bola area records at least three major glacial/deglacial cycles (Fig. 1; Valdez et al., 2015) and several minor transgressive-regressive ( $\mathrm{T}-\mathrm{R})$ successions. The regressive onset of the Glacial-Deglacial Cycle 2 is marked by a $\leq 90 \mathrm{~m}$ thick pile related to a southward delta progradation (Fluvio-Deltaic II, Fig. 1). It is followed by an up to $188 \mathrm{~m}$ thick composite unit (Megabed I, including the $180 \mathrm{~m}$ thick MTD II of Dykstra et al., 2011, see below), deposited following 

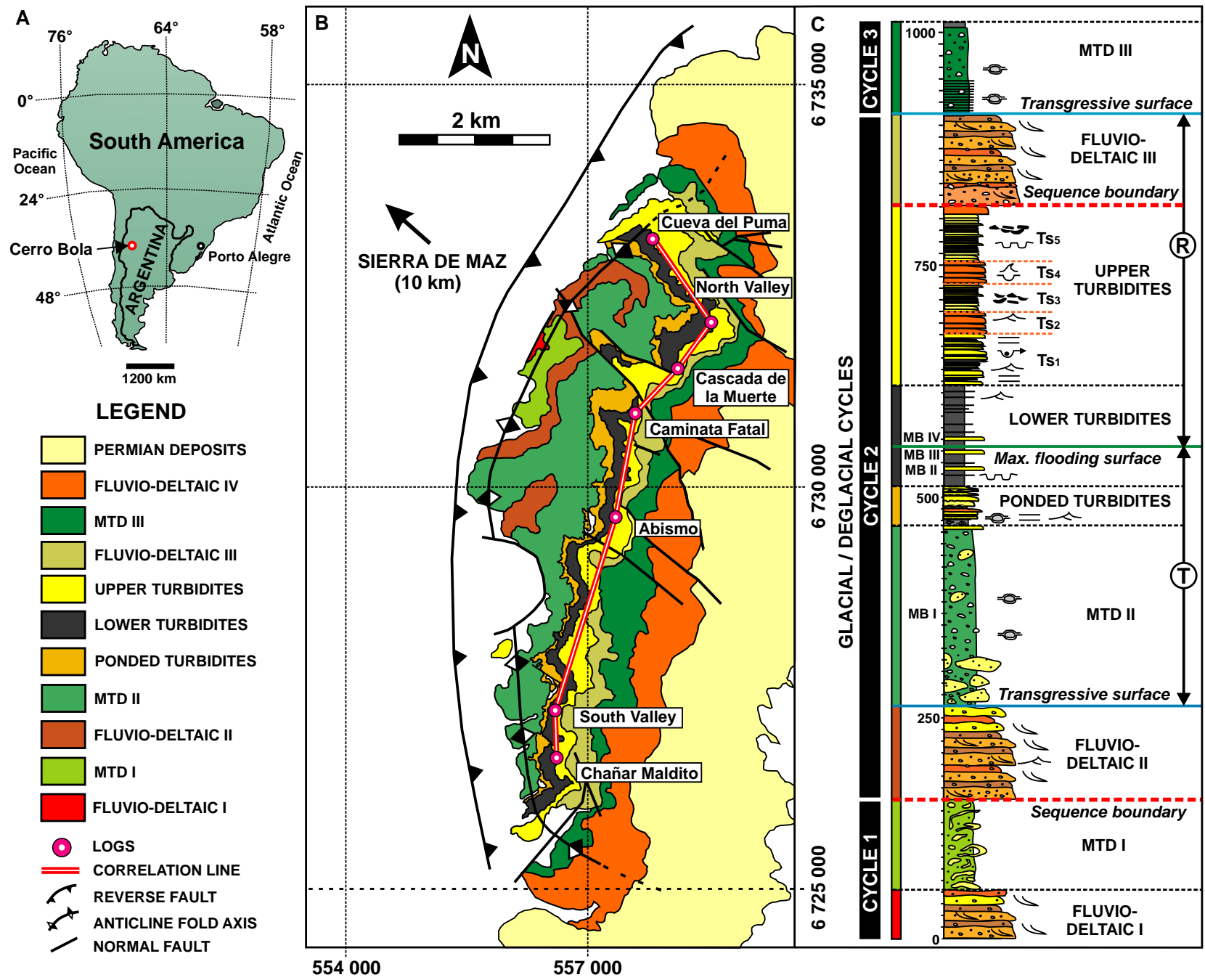

Fig. 1. (A) Location of the study area in central western Argentina. (B) Geological map of the Cerro Bola area (modified from Dykstra et al., 2011) and location of sedimentary logs. (C) Composite stratigraphic log of part of Cerro Bola exposure showing the glacial/deglacial cycles and associated transgressive-regressive pulses. Megabeds are positioned within the Lower Turbidites. MTD, mass-transport deposit; MB, megabed.

substantial transgression (Figs 1 and 2). Above the composite unit occurs a $c a 2$ m thick varvelike, dropstone-bearing unit that is followed by up to $60 \mathrm{~m}$ of sheet-like turbidite sandstones (Ponded Turbidites, Figs 1 and 2), which records renewed sediment supply due to a minor lowstand. The sedimentation of these turbidites was strongly controlled by the underlying topography, indicated by significant changes in their overall thickness (Kneller et al., 2016).

As part of the continuing transgression, an $80 \mathrm{~m}$ thick mudstone/siltstone-dominated succession (Lower Turbidites, Figs 1 and 2) was deposited immediately above the Ponded Turbidites. The Lower Turbidites represents a flooding zone with regional significance, being associated with a synchronous flooding recorded widely in the eastern Paganzo Basin (Limarino et al., 2002; Kneller et al., 2004; Dykstra et al., 2006; Limarino \& Spalletti, 2006). The Lower Turbidites consists largely of silty mudstones with thin-bedded turbidites (tbt) composed of plane-bedded and ripple cross-laminated sandstones, but also includes three of the megabeds described here (Fig. 2). The correlative transgressive unit elsewhere on the western basin margin also includes megabeds (Quebrada Grande, Stage III; Kneller et al., 2004; Las Lajas, Stage 2; Dykstra et al., 2006). Palaeocurrent readings on flute casts and grooves from the turbidites are consistently towards the north or north-west, while those related to ripples display more scattered 

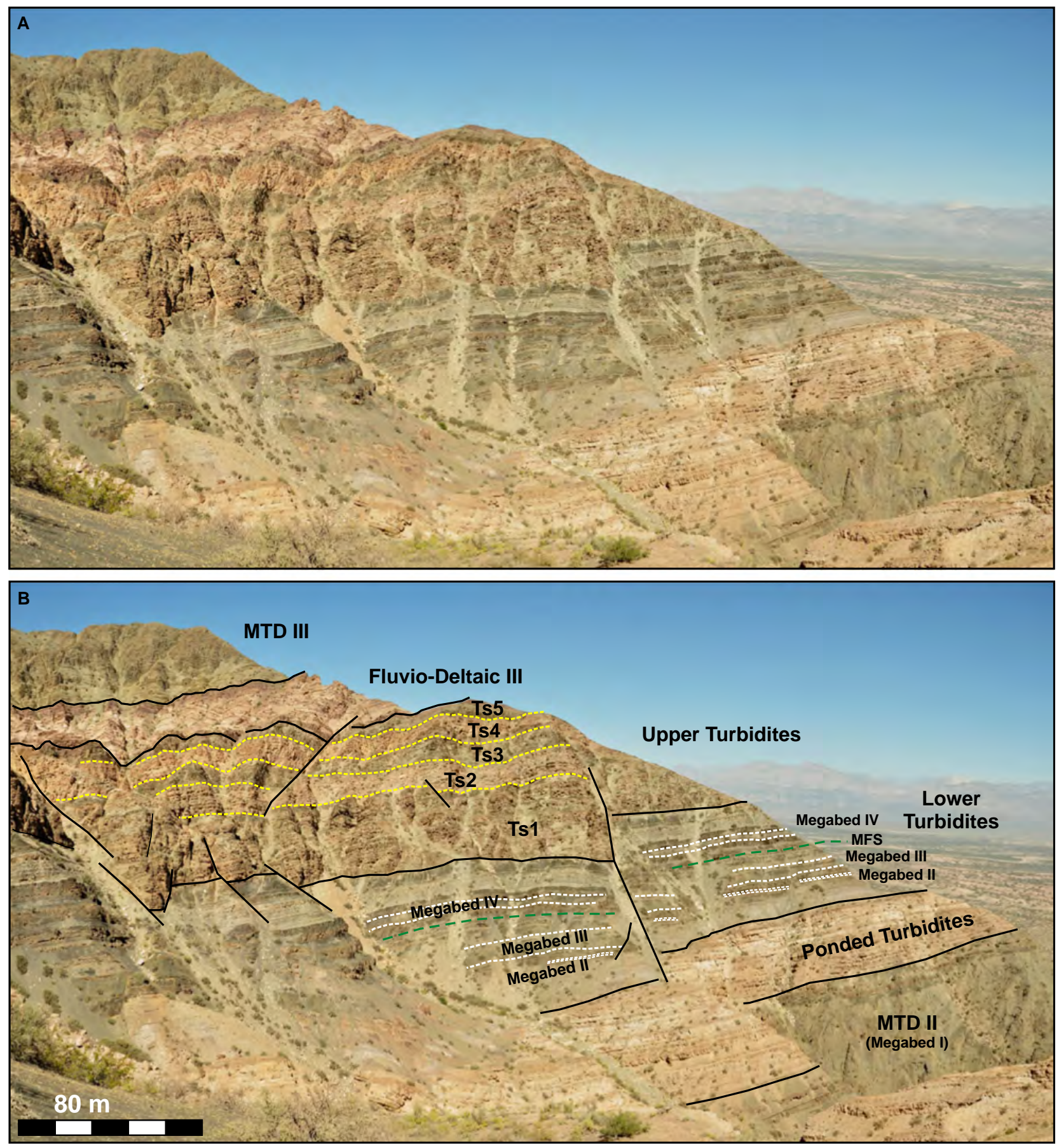

Fig. 2. (A) View to the south of Cerro Bola showing the almost complete stratigraphy succession and megabeds position. (B) Interpreted sketch of (A). Note that the Lower Turbidites comprises a mudstone-rich interval that includes the flooding zone and at least three megabeds.

directions, indicating multiple sources or possibly reflection and deflection against the basin margin. This mudstone-dominated interval also includes thicker, usually amalgamated, sandstone beds. In addition, it comprises a 4 to $5 \mathrm{~m}$ thick, evenly banded unit composed of mudstones and thin, very fine-grained rippled sandstones. This unit is a distinctive stratigraphic marker in Cerro Bola and in the Sierra de Maz inlier to the north-west of Cerro Bola (which restores to a pre-tectonic separation of $\mathrm{ca}$ $15 \mathrm{~km}$ after removal of thrust displacement), 
where the same stratigraphic units onlap the metamorphic basement, denoting a basin margin setting.

The onset of the normal regressive phase of the glacial/deglacial cycle 2 is recorded by a $120 \mathrm{~m}$ thick interval of sand sheet turbidites (Upper Turbidites, Figs 1 and 2), which is subdivided into five stages $\left(\mathrm{Ts}_{1}\right.$ to $\left.\mathrm{Ts}_{5}\right)$. These deposits comprise turbidites and some beds that resemble hybrid facies (Haughton et al., 2009). The former display abundant sole marks (flutes and grooves) and ripple cross-lamination that indicate transport to the north or north-west. Beds interpreted as hyperpycnites (based on their inverse to normal grading profiles) are also present, and show a north to north-east trend of palaeocurrents. The Upper Turbidites are abruptly overlain by up to $165 \mathrm{~m}$ of fluvio-deltaic sandstones (Fluvio-Deltaic III, Figs 1 and 2). This suggests a sea-level fall with a shallowing from very sandy, flood-dominated pro-delta gravity flow deposits to an emergent delta top. A deeply incised $(>60 \mathrm{~m})$ surface cuts into the upper surface of the deltaic deposits and is overlain by a succession of large mass movement deposits (MTD III, Figs 1 and 2). Similar to MTD II, they also contain dropstone-bearing facies. Moreover, the top of Fluvio-Deltaic III records some striations and polished surfaces, possibly indicating a glacial advance (glacial/ deglacial cycle 3, Fig. 1), as also occurs elsewhere in the Paganzo Basin (Quebrada Grande, Stage V, of Kneller et al., 2004).

\section{METHODS}

Approximately $300 \mathrm{~m}$ of detailed sections were measured through the modern valleys at the Cerro Bola inlier, represented by seven logs of $c a$ $40 \mathrm{~m}$ each at a scale of 1:100. Spectral gamma-ray profiles were prepared from CPS (counts per second) readings at intervals of $30 \mathrm{~cm}$. The flooding zone associated with the Lower Turbidites contains a thick interval of black shales whose higher gamma-ray value is associated with the largest thorium and uranium content, and has been used as a datum (maximum flooding surface) to aid in correlation of the megabeds. A correlation panel of over ca $8 \mathrm{~km}$ was made in order to characterize the continuity of the megabeds as well as the geometry of their internal divisions. Exceptional exposure allowed the megabeds to be walked out on the ground for several kilometres between logged sections. Individual megabeds were logged in higher detail (1:20), with gamma-ray readings at intervals of $10 \mathrm{~cm}$. Trends in sediment dispersal were provided by more than 115 measured palaeocurrent indicators. Mud contents were quantified using thin sections with 300 point counts each, using a standard petrological microscope. Measured sections, gamma-ray readings and petrographic analysis were then combined with outcrop descriptions and ground photomosaics to support interpretation. An oriented hammer is used as scale in several photographs, the head being parallel to bedding and the handle pointing upward. The chisel on the hammer head points approximately downcurrent.

\section{RESULTS}

\section{Cerro Bola Megabeds}

The Cerro Bola area includes several large (many tens of metres thick) chaotic or structureless deposits interpreted by Dykstra et al. (2011) as mass-transport deposits (MTDs; Fig. 1). One of these (MTD II) is immediately followed by a sandstone bed (Unit A of Kneller et al., 2016) and the two together are here considered as a single megabed (Megabed I). This outsize megabed shares a number of features in terms of depositional process with three other, smaller megabeds that occur at a different stratigraphic level (Lower Turbidites; Figs 1 and 2). These three megabeds (Megabeds II, III and IV) are located within the flooding zone, two of them below the maximum flooding surface datum and one above it; they are completely distinct from the surrounding thin-bedded turbidites and mudstones. The megabeds range from $3 \mathrm{~km}$ to more than $20 \mathrm{~km}$ in lateral extent because three of them are also present in the adjacent Sierra de Maz inlier. The megabeds were subdivided, on the basis of their textures, into divisions 1,2 and 3 (not all of which may be present in any one megabed) that together constitute an idealized deposit.

\section{Megabed I}

Megabed I is represented by a very thick deposit (188 $\mathrm{m}$ at Cerro Bola and up to $200 \mathrm{~m}$ at Sierra de Maz) and constitutes an outstanding seismicscale outcrop example of this type of deposit, extending for more than $8 \mathrm{~km}$ in continuous oblique to dip section along the Cerro Bola inlier. Megabed I is classified here as a bipartite 

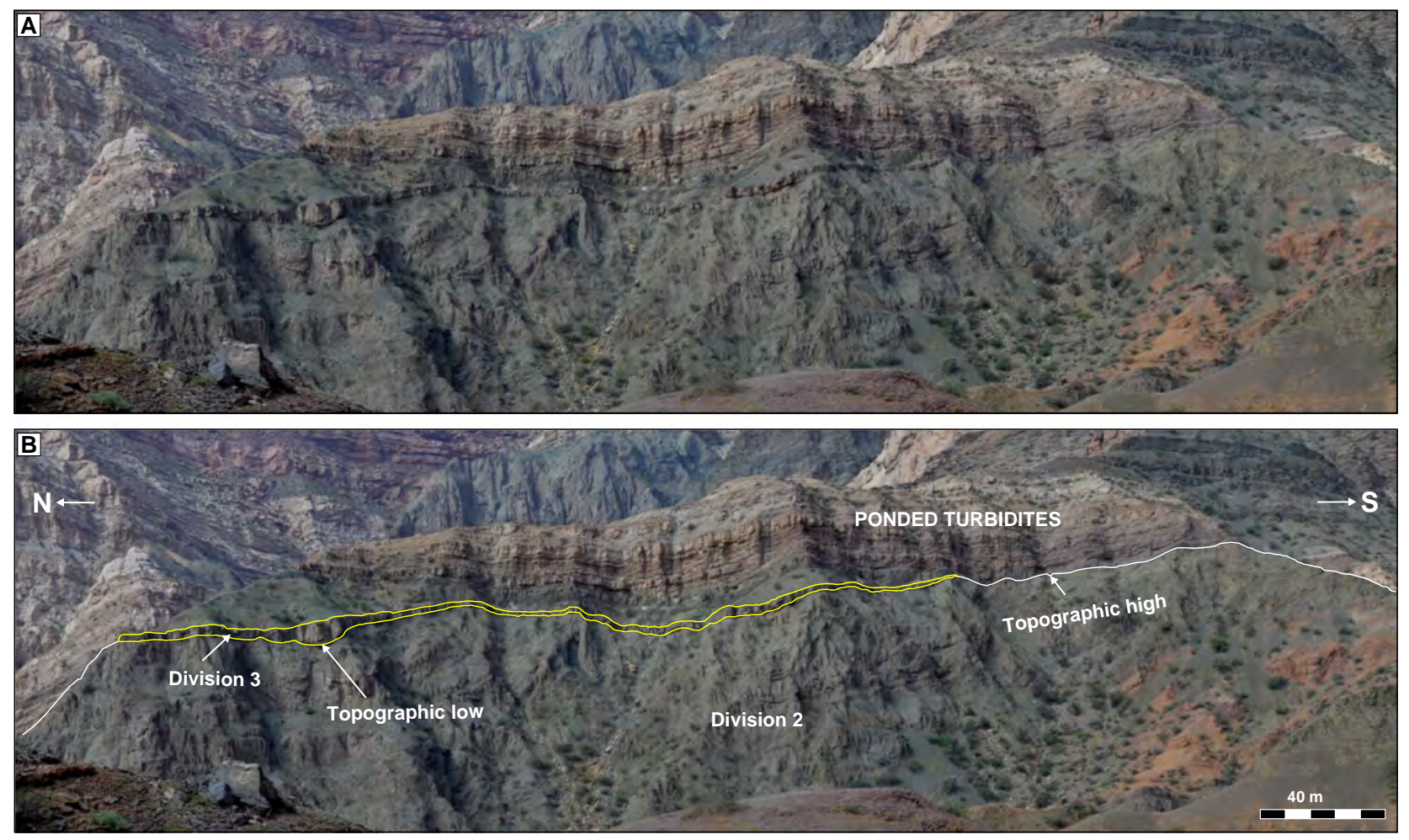

Fig. 3. Upper half of Megabed I (the base is not observed from this view). (A) Outcrop between North Valley and Cascada de la Muerte sections. (B) Interpreted sketch of (A), showing negative (left-hand side of photograph) and positive (right-hand side of photograph) relief at the top of division 2. The topographic lows were firstly filled by division 3 deposits.

megabed, comprising divisions 2 and 3 (Figs 3 and 4) because division 1 is not present. Division 2 is $\leq 180 \mathrm{~m}$ thick and can be subdivided into three broad intervals on structural grounds (divisions 2a, 2b and 2c, Fig. 4), equivalent to the lower, middle and upper zones of Dykstra et al. (2011) and Sobiesiak et al. (2016b).

Division 2a contains a notable concentration of very large sandstone blocks (Fig. 5A and B) comparable to the underlying fluvio-deltaic deposits (Fluvio-Deltaic II, Fig. 1; Dykstra et al., 2011; Sobiesiak et al., 2016a). The sandstone blocks are supported by very fine-grained sandstone to siltstone matrix; they are up to tens of metres across, some of them with preserved primary sedimentary structures. Their disaggregation by shearing formed sand streaks within the matrix that decrease in abundance away from the blocks, leading to increased sand content in the matrix (Dykstra et al., 2011; Sobiesiak et al., 2016a). Because the allochthonous sand blocks are more rigid than the matrix of division 2, zones of high strain tend to develop around them (Sobiesiak et al., 2016a) and individual sandstone blocks are usually broken by stretching and boudinage (Fig. 5A and B; Dykstra et al., 2011) or compressed.

Division $2 \mathrm{~b}$ is represented mostly by laminated siltstone rafts several metres thick and many tens of metres long, considered to be the lessdeformed remnants of the protolith. It contains a chaotic distribution of granule to boulder size clasts of granitoids and metamorphic basement rocks enveloped and supported by a dominantly greenish, fine-grained matrix. Some of these clasts exhibit glacial striations, smooth-faceted shapes, and within the protolith rafts surrounding lamina disruption that suggests a dropstone origin. Relative to division 2a, this one presents a smaller content of sandstone blocks, less intense shearing at their borders, and therefore a lower sand content in the matrix. Division $2 \mathrm{~b}$ is also structurally complex, with both compressional and extensional features occurring alone or overprinted (Dykstra et al., 2011; Sobiesiak et al., 2016b). Division 2c consists of folded and sheared siltstones to mudstones showing a predominance of thrust structures dipping $\mathrm{Ca} 20^{\circ}$ to the east (Dykstra et al., 2011). Sandstone blocks 


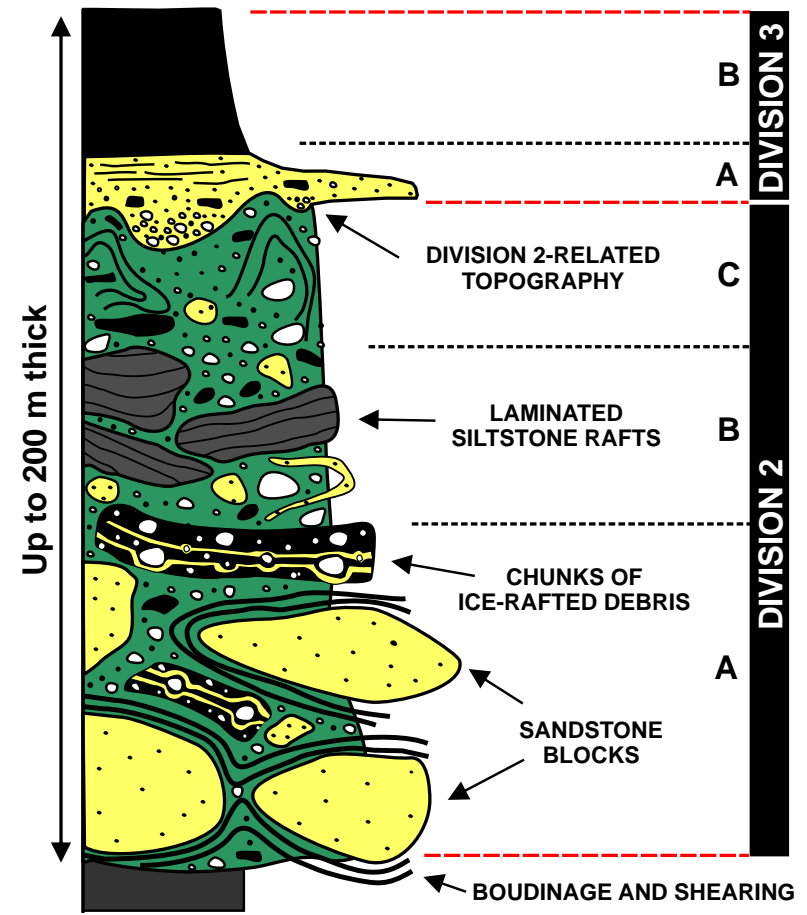

Fig. 4. Schematic log of the bipartite Megabed I showing its main sedimentary features and internal divisions (bed not to scale). Large blocks of sandstone are concentrated near base and decrease in size and abundance upward. Large fragments of siltstones containing dropstones are considered to be relicts of an IRD protolith.

are rare, and overall there is an upward fining of the largest blocks.

The top of division 2 created an irregular topography that controlled and partially pnfined deposition of the subsequent graded 2 nd-stone to mudstone bed (Dykstra et al., 2011) here classified as division 3 (Figs 3 and 4; Unit A of Kneller et al., 2016). Division 3 is restricted to isolated lenses, 10 to $250 \mathrm{~m}$ in outcrop length and up to $8 \mathrm{~m}$ thick. Division 3 pinches out against (and locally slumps off) division 2 topographic highs. The present lows in the upper surface of division 2 are up to $50 \mathrm{~m}$ deep due to post-depositional creep and/or compaction, and do not coincide precisely with the thicker sections in division 3 (Kneller et al., 2016). Division 3 is normally graded and includes massive to laminated, very coarse to fine-grained sandstone (division 3a) capped by siltstone and mudstone (division $3 \mathrm{~b}$ ) from suspension fallout. The sandstone division is dark green, matrix-rich and contains granules to pebbles of metamorphic and igneous rocks at its base.

\section{Megabed II}

Megabed II is the thinnest of the megabeds at Cerro Bola (0.5 to $1.0 \mathrm{~m}$; Figs 6 and 7) and has an outcrop extent of $c a 2.5 \mathrm{~km}$. It is confined to the northern valleys of Cerro Bola and is best exposed in the Cascada de la Muerte section (Fig. 8A and B). Despite its relatively thin nature, the term megabed is retained in part because there is a lack of appropriate definition related to the thickness [e.g. Ricci Lucchi \& Valmori (1980) proposed megabeds $\geq 1 \mathrm{~m}$ thick] and also because of its distinct aspect relative to the surrounding rocks, in terms of both thickness and inferred depositional process.

Megabed II is a tripartite bed, represented by three distinct intervals (divisions 1 to 3 , Figs 7 and 8). Division 1 is a 0.03 to $0.2 \mathrm{~m}$ thick interval of small pebble to granule-rich, clastsupported conglomerate. It is occasionally normally graded (Fig. 8C) and displays a few centimetres of erosion into underlying mudstones and sandstones. Pebbles are extra-basinal, rounded to sub-rounded crystalline clasts. In a few localities, this division is missing and replaced by blocks and pieces of sandstone beds (Fig. 8A) and smaller laminated mudstone rafts.

Division 2 is up to $0.6 \mathrm{~m}$ thick and comprises ungraded, matrix-supported conglomerate. Its matrix is composed of mud-rich sandstone that encloses granules and small to medium, rounded to sub-rounded pebbles of extra-basinal and intra-basinal origin. Some of the intra-basinal clasts preserve their original structures and consist of muddy slabs, fragments of sandstones and cohesive rafts of thin sand to mud beds (Fig. 8B) and correspond to background deposits. Occasionally, the large sandstone clasts show some sort of normal grading through division 2 as they become smaller and less frequent towards the top (Fig. 8A). Mudstone chips and clasts are abundant, with their long axis parallel to bedding.

A $\leq 0.3 \mathrm{~m}$ thick, normally graded, sand to mud interval defines division 3 that sharply overlies division 2. This interval is further subdivided in terms of textural elements (divisions $3 \mathrm{a}$ and $3 \mathrm{~b}$; Fig. 7). Division 3a is composed of normally graded, fine- to very fine-grained sandstone that can be either faintly laminated or massive. The top of division 3a includes interference ripples (Fig. 8D) with cross-laminations showing palaeocurrents mainly to ENE, ESE and WSW. Division 3a grades upward into siltstone and 

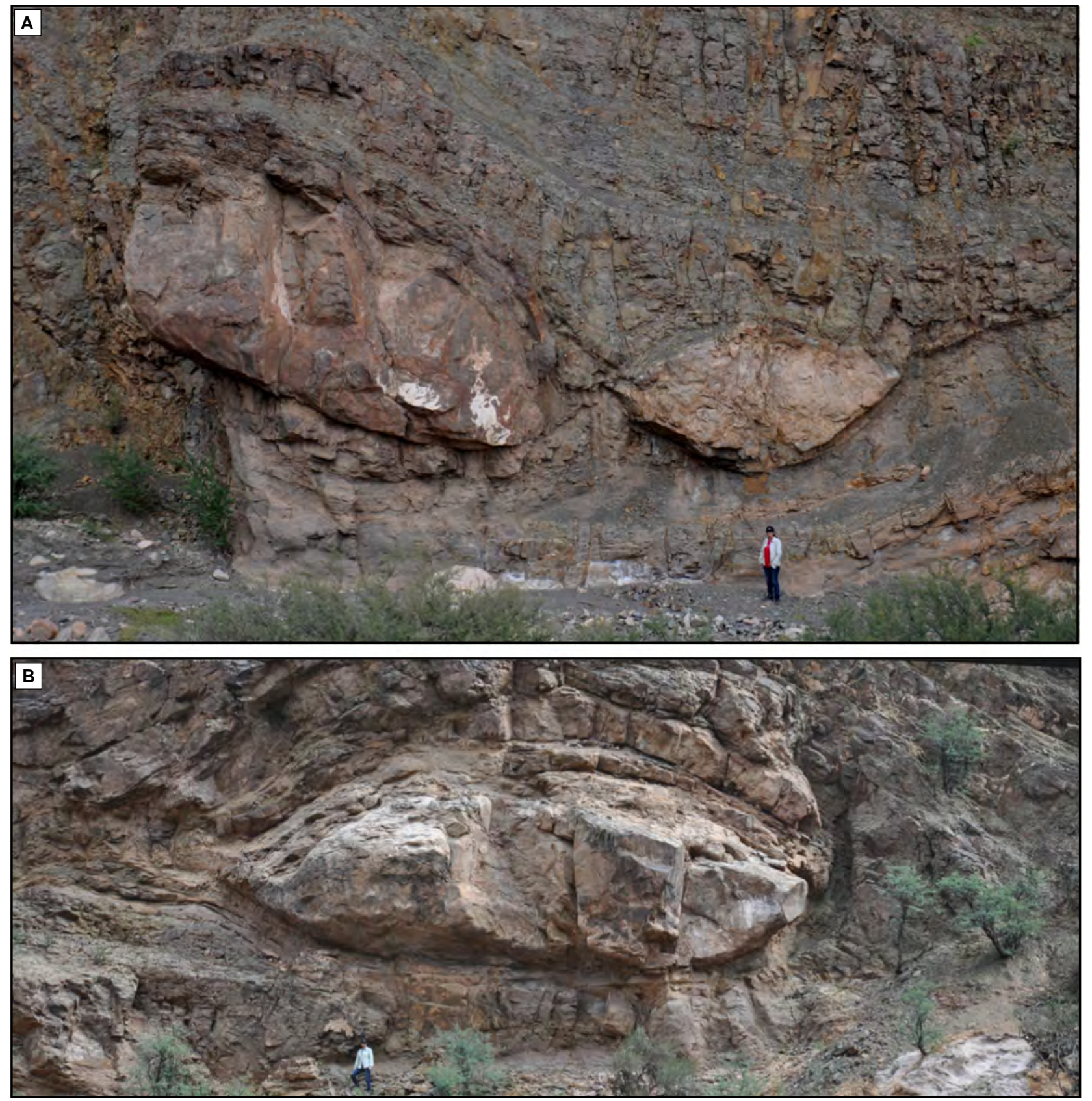

Fig. 5. (A) and (B) Sandstone boulders incorporated into division 2. Note the boudinage-like structures, produced by shearing around the sandstone blocks. Above sandstone blocks in photo (A) a large, deformed fragment ascribed to an ice-raft debris (IRD) protolith is observed. Note a person for scale ( $c a 1.8 \mathrm{~m}$ tall) in both photographs.

mudstone of division $3 \mathrm{~b}$, which may also overlie division 2 directly when the sand fraction (3a) is absent. The top of division 2 is an irregular surface with topographic lows that range from 0.1 to $0.4 \mathrm{~m}$ deep and 0.5 to $1.0 \mathrm{~m}$ wide. These lows and highs on which the subsequent division 3 is deposited result in sudden thickness changes in division $3 \mathrm{a}$ (the sand fraction of division 3) from $0.2 \mathrm{~m}$ to $0 \mathrm{~m}$, which thus includes areas of non-deposition.

\section{Megabed III}

Megabed III is up to $9 \mathrm{~m}$ thick and shows a tripartite organization, whose three divisions are very similar to those in Megabed II (Figs 6 and 7). Megabed III has an outcrop extent of more (C) 2016 The Authors. Sedimentology (C) 2016 International Association of Sedimentologists, Sedimentology 


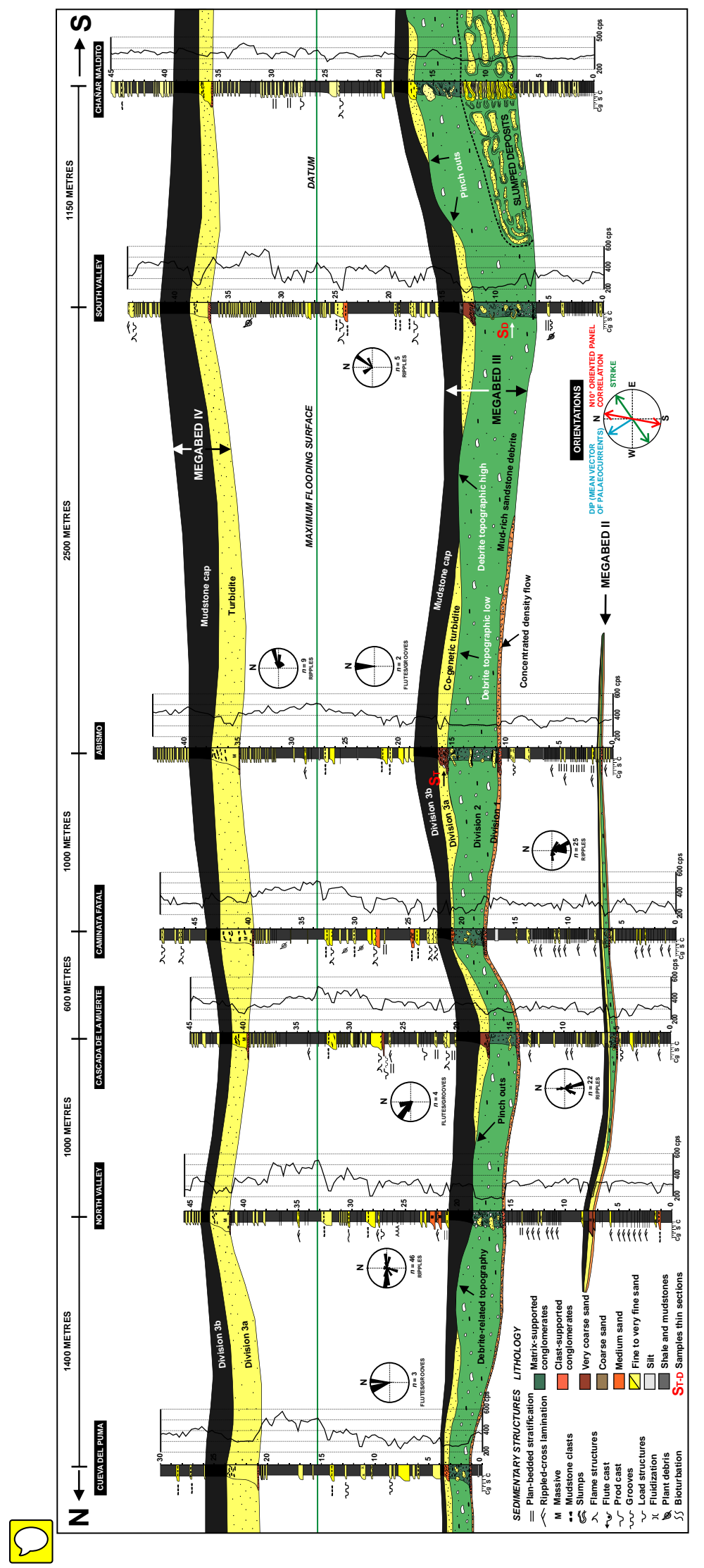

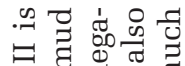

- घ 명 ह

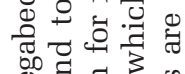

$\sum$ क क

ठृं क्ष

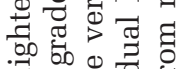

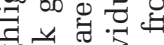

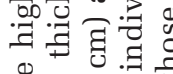

范

$\geq \lambda \ddot{\bar{\sigma}} \overline{0}: \frac{1}{3}$

드윻워

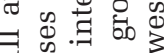

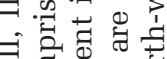

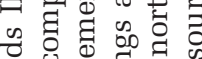

o $0 . \exists$ :

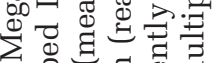

त

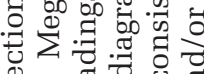



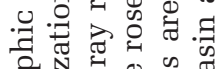

원. 군

50 대 द्व

ॠ

क 100 क 30

ช

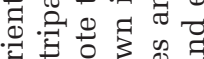

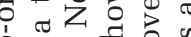

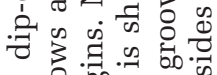

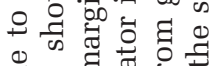

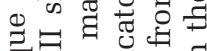

.

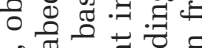

ô

이웡

药㐘

$人=\Phi \frac{\pi}{\pi} .0$

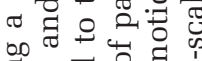

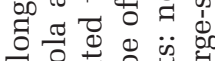

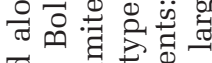

ष्.

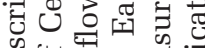

ब्रे

os

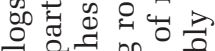

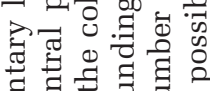

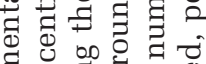

.

क ग्ञ त्व

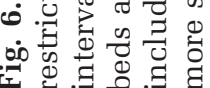

(C) 2016 The Authors. Sedimentology (C) 2016 International Association of Sedimentologists, Sedimentology 


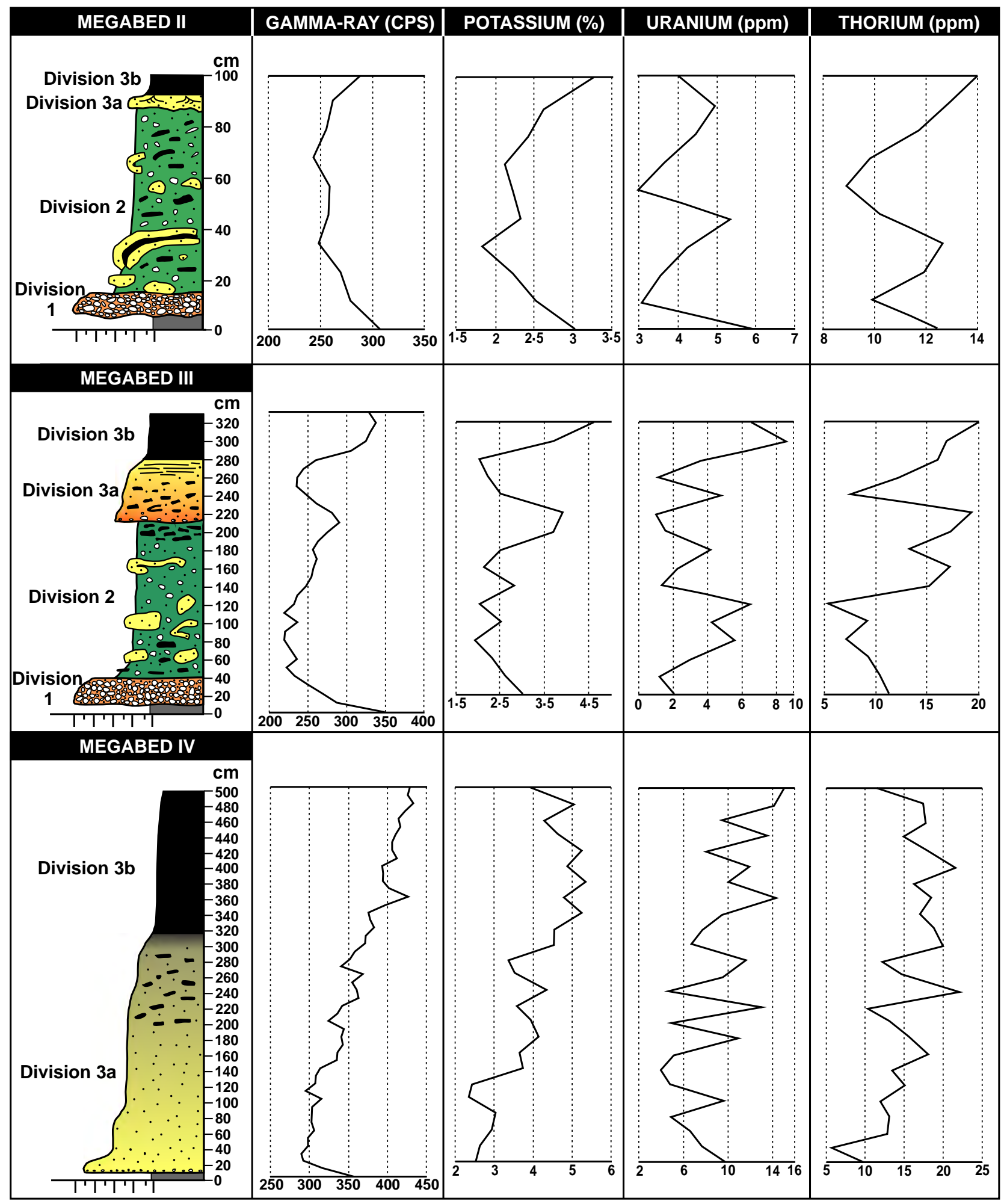

Fig. 7. Detailed logs of megabeds showing both the internal divisions at the moment of deposition and the gamma spectrometer signatures of the potassium, uranium and thorium channels (reading interval: $10 \mathrm{~cm}$ ). Note that Megabeds II and III show a tripartite organization while Megabed IV comprises a single division in the Cerro Bola area. Megabed II: Cascada de la Muerte section, Megabeds III and IV: Cueva del Puma section. 

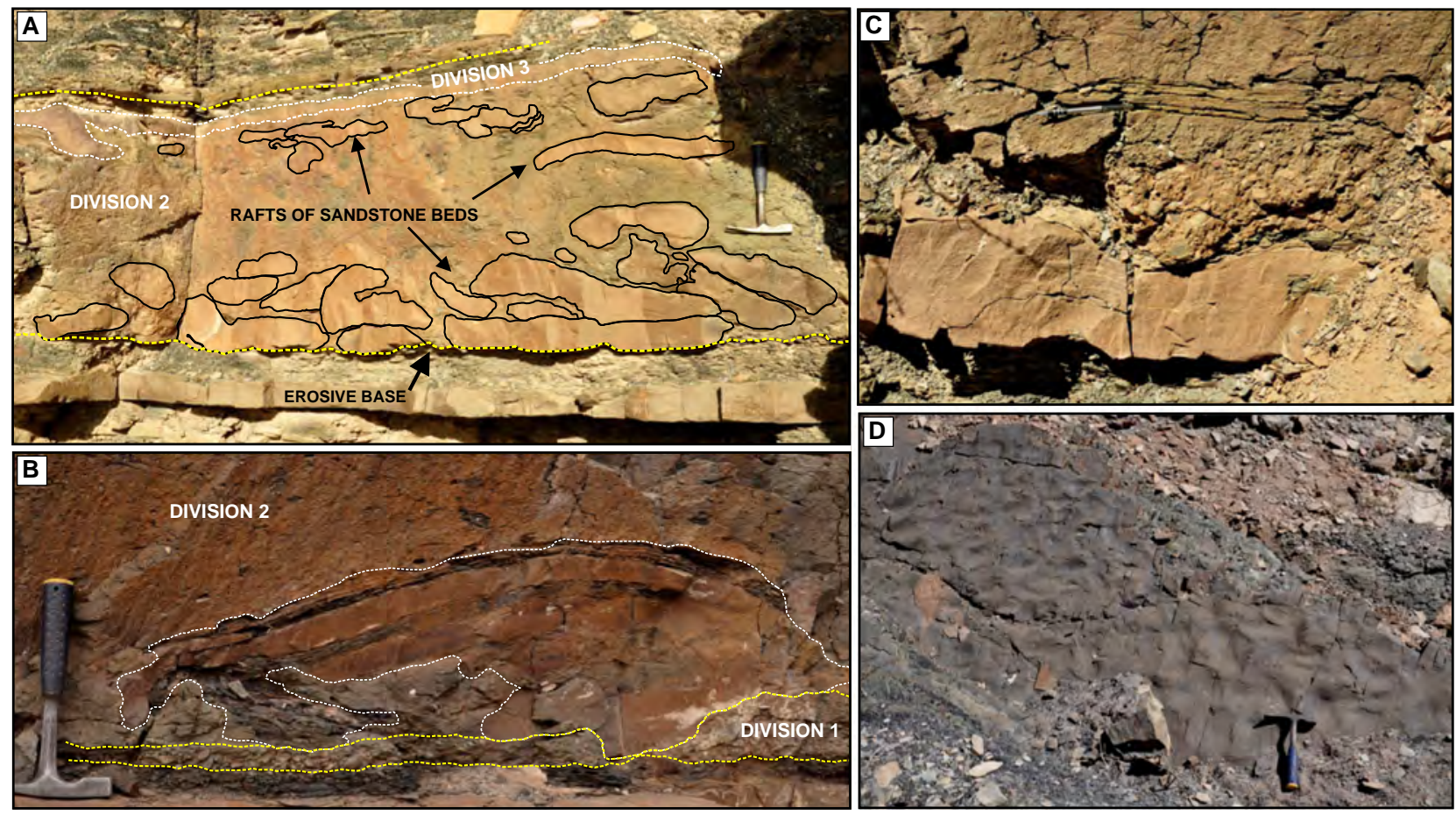

Fig. 8. Sedimentary features of Megabed II in the Cascada de la Muerte section. (A) Note the stacked, faintly deformed sandstone clasts near the base and top of division 2, followed by a thin, sand to mud bed (division 3). Division 1 is missing and it is replaced by large fragments of sandstone beds. Dashed yellow and white lines indicate bed boundaries and internal divisions, respectively. Hammer for scale is $30 \mathrm{~cm}$ long. (B) Near-base cohesive raft of thin sand to mud layers (white line contour), within division 2, considered as turbidite beds plucked from underlying strata. Note that division 1 is present (yellow lines). (C) Erosive contact of division 1 and underlying sandstone. Note the normally graded nature of the pebbly to very coarse-grained sandstone of division 1 (pen for scale is $14 \mathrm{~cm}$ long). (D) Plan view of interference ripples at the top of division 3a, showing multiple flow directions.

than $7.5 \mathrm{~km}$ and can be followed across the entire Cerro Bola inlier (Fig. 6). It is best exposed in the Abismo (Fig. 9A) and South Valley sections. It is also present in the Sierra de Maz inlier $10 \mathrm{~km}$ to the north-west, which restores to a pre-tectonic separation of $c a 15 \mathrm{~km}$. To the south, Megabed III includes a basal slumped unit in place of division 1, which extends for more than $1 \mathrm{~km}$ (Fig. 6).
Division 1 is 0.2 to $0.6 \mathrm{~m}$ thick and can be subdivided into $1 \mathrm{a}$ and $1 \mathrm{~b}$. The variation in thickness of division 1 is mainly due to scours, a few centimetres deep filled by clast-supported conglomerates (Fig. 9B). Subdivision 1a comprises clast-supported and matrix-supported conglomerates characterized by a high concentration of rounded to sub-rounded, extra-basinal granules, small to large pebbles and cobbles

Fig. 9. (A) General view and internal divisions of Megabed III at the Abismo section. Notice the anomalous thickness of this megabed relative to the surrounding strata. Cohesive rafts and pieces of sandstone beds are present within division 2. Note that the irregular morphology of division 2 creates pond shapes that capture and partially confine the following division 3a. Circled person for scale (ca $1.8 \mathrm{~m}$ tall). Dashed yellow lines = base and top of the megabed. Dashed white lines = megabed internal divisions. (B) Erosion at the base of division 1 and resulting lenticular bodies of clast-supported conglomerates. Note that these deposits are followed by the division 2, which contains many large clasts of mudstone. Hammer for scale is $30 \mathrm{~cm}$ long. (C) Solely clast-rich dominated interval of division 1. Lens cap is $7 \mathrm{~cm}$ in diameter. (D) Division 1a, composed of clast-supported, pebble-rich and granule-rich conglomerate sometimes replaced by (E) matrix-supported, pebble conglomerate. Pen for scale is $14 \mathrm{~cm}$ long. (F) and (G) Rare examples of division 1 comprising two distinct intervals: granules and pebbles (division 1a) overlain by weak normal-graded $(F)$ and ungraded $(G)$, small pebbles to coarse-grained sand (division 1b). 

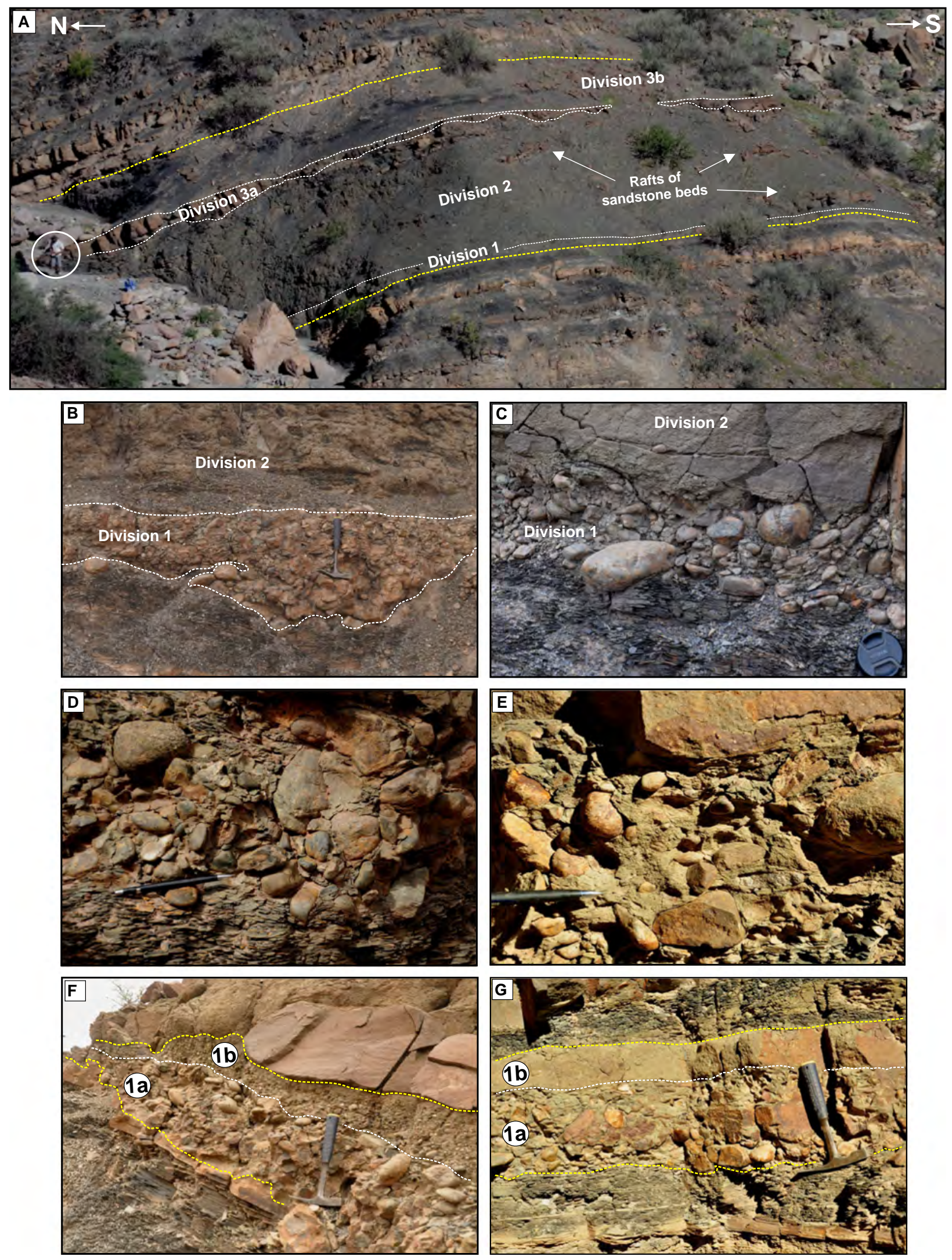
(Fig. 9C, D and E). Subdivision 1a is dominant along the base of Megabed III. Subdivision 1b is composed of very coarse to coarse-grained sandstone with scattered granules and small pebbles, being absent in places. Although usually ungraded, it occasionally displays a subtle normally grading (Fig. 9F and G). The contact between the two subdivisions is abrupt to transitional.

Division 2 is up to $6 \mathrm{~m}$ thick and characterized by ungraded, poorly sorted, matrix-supported conglomerate. Its matrix is composed of mud-rich sandstone, which supports scattered, rounded to sub-rounded crystalline clasts (mainly gneisses and granitoids, Fig. 10A). Larger cohesive rafts of sand to mud beds (Fig. 10B), as well as muddy slabs and blocks and boulders of sandstones, are concentrated in the lower half of division 2, becoming smaller upward. Folded sandstone beds are more frequent near the top (Fig. 10C). The mud-rich sandstone matrix often contains randomly oriented, rotated blocks and sheared boulders of sandstone (Fig. 10D) with irregular shapes, commonly with sand streaks derived from them and assimilated within the matrix. Mudstone clasts are also common, and abundant throughout the entire division 2, although they are more frequent near the base or top. Larger mudstone clasts $(0.1$ to $0.8 \mathrm{~m})$ are oriented parallel to bedding. Division 2 also contains rare, dispersed, small fragments of fossil wood.

The contact between divisions 2 and 3 can be either transitional or sharp, irregular and apparently controlled by the upper relief of division 2 , producing topographic lows and highs that makes it the likely cause of the thickness changes in division 3 (from 0 to $1 \mathrm{~m}$, see Fig. 9A). Division 3 fills up the division 2-related topography generating pinch-out or thin-out relations along a dip-section. At outcrop, the pond-like topography ranges from $0.2 \mathrm{~m}$ to $>1.0 \mathrm{~m}$ high and 1 to $4 \mathrm{~m}$ wide. Furthermore, this contact is marked by deformation structures such as folding and mud injections (Fig. 10E).

Division 3 consists of a $\leq 3 \mathrm{~m}$ thick sand to mud interval that can be further subdivided into 3a and 3b. Division 3a can be up to $1 \mathrm{~m}$ thick and is composed of very coarse-grained, massive sandstone (Fig. 10F) that includes abundant mudstone chips and clasts, as well as granules and small to medium pebbles. This interval grades upward into medium-grained, massive sandstone with local mudstone clast concentrations and rare, dispersed pebbles (Fig. 10G) that in turn passes upward into fine-grained and very fine-grained sandstone with faint lamination (Fig. 10H). The coarse-grained fraction of division 3 is apparently restricted to the topographic lows on the top of division 2, whereas on topographic highs the fine-grained fraction is deposited. Local higher topographies may lead to non-deposition of division 3a, with division 2 being directly overlain by division 3b. Locally, where the negative topography of the top of division 2 is more pronounced, subtle grain-size breaks are developed and marked either by concentrations of coarse grains or small mudstone clasts. The following division (3b) consists of a $\leq 2 \mathrm{~m}$ thick black mudstone cap.

Slumped unit of Megabed III: In the southernmost $1 \mathrm{~km}$ or so of the Cerro Bola inlier, a $4 \mathrm{~m}$ thick slump unit replaces division 1 at the base of Megabed III (see Fig. 6). This slump is composed of very coarse to medium-grained, folded and fragmented sandstone beds (Fig. 11A to C). These beds show normally graded profiles and are enveloped by silty sandstone matrix with dispersed granules to small pebbles. Where the slump is present, a $1.5 \mathrm{~m}$ thick muddier interval is present at the top of division 2, composed of deformed siltstones, mudstones and sandstones showing a sheared fabric and chevron-like folding with associated mud injections into the overlying division 3. Division 3 is persistent and also occurs where the slump unit is present but division 3a is thinner (up to $0.2 \mathrm{~m}$ ) when compared with the other places along the outcrop (up to $1 \mathrm{~m}$ ). The coarse-grained fraction fills shallow topographic depressions in the muddier top of division 2, forming normally graded sandstone lenses ca $0.8 \mathrm{~m}$ long and $0.2 \mathrm{~m}$ thick, pinching out against adjacent topographic highs (Fig. 11D).

\section{Megabed IV}

In the Cerro Bola area, Megabed IV includes only one division (Figs 6 and 7), equivalent to division 3 of the other megabeds; an ungraded, chaotic division component is present in the Sierra de Maz inlier, similar to division 2 of Megabeds II and III, but much thinner. Therefore, Megabed IV is considered to be a bipartite megabed. The only division present in Cerro Bola (equivalent to division 3) comprises a thick (up to $6 \mathrm{~m}$ ) sand to mud graded bed (Fig. 12A) that can be followed throughout the entire inlier, being best exposed in the Caminata Fatal and Cascada de la Muerte valleys. Its thickness 

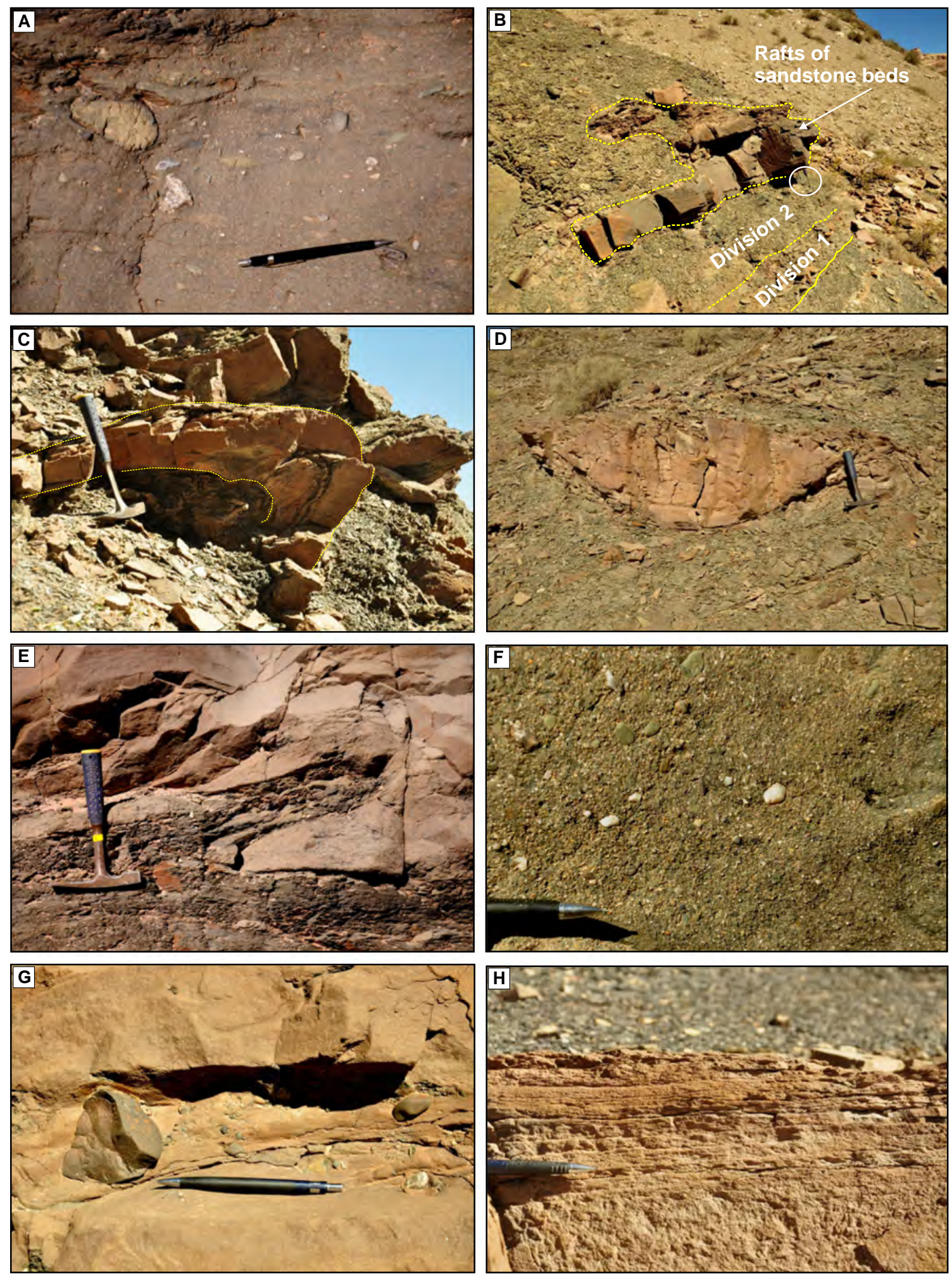

Fig. 10. Examples of features related to division 2 (A) to (D) and to division 3 (E) to (F) of Megabed III. Pen for scale is $14 \mathrm{~cm}$ long. (A) Sandy mud-matrix involving dispersed pebbles and granules, often including (B) large cohesive raft of sand to mud beds concentrated near the base (circled hammer for scale is $30 \mathrm{~cm}$ long). (C) Folded sandstone beds usually at the top of division 2. (D) Sheared margins of sandstone blocks. (E) Local mud injection into division 3a. (F) Coarse to very coarse sandstones at the base of division 3. (F) Mid portion of division 3a showing scattered pebbles and granules; and $(G)$ fine to very fine-grained sandstone with faint lamination at the top of di $\rightarrow$ 3a.

(C) 2016 T Thors. Sedimentology (c) 2016 International Association of Sedimentologists, Sedimentology 

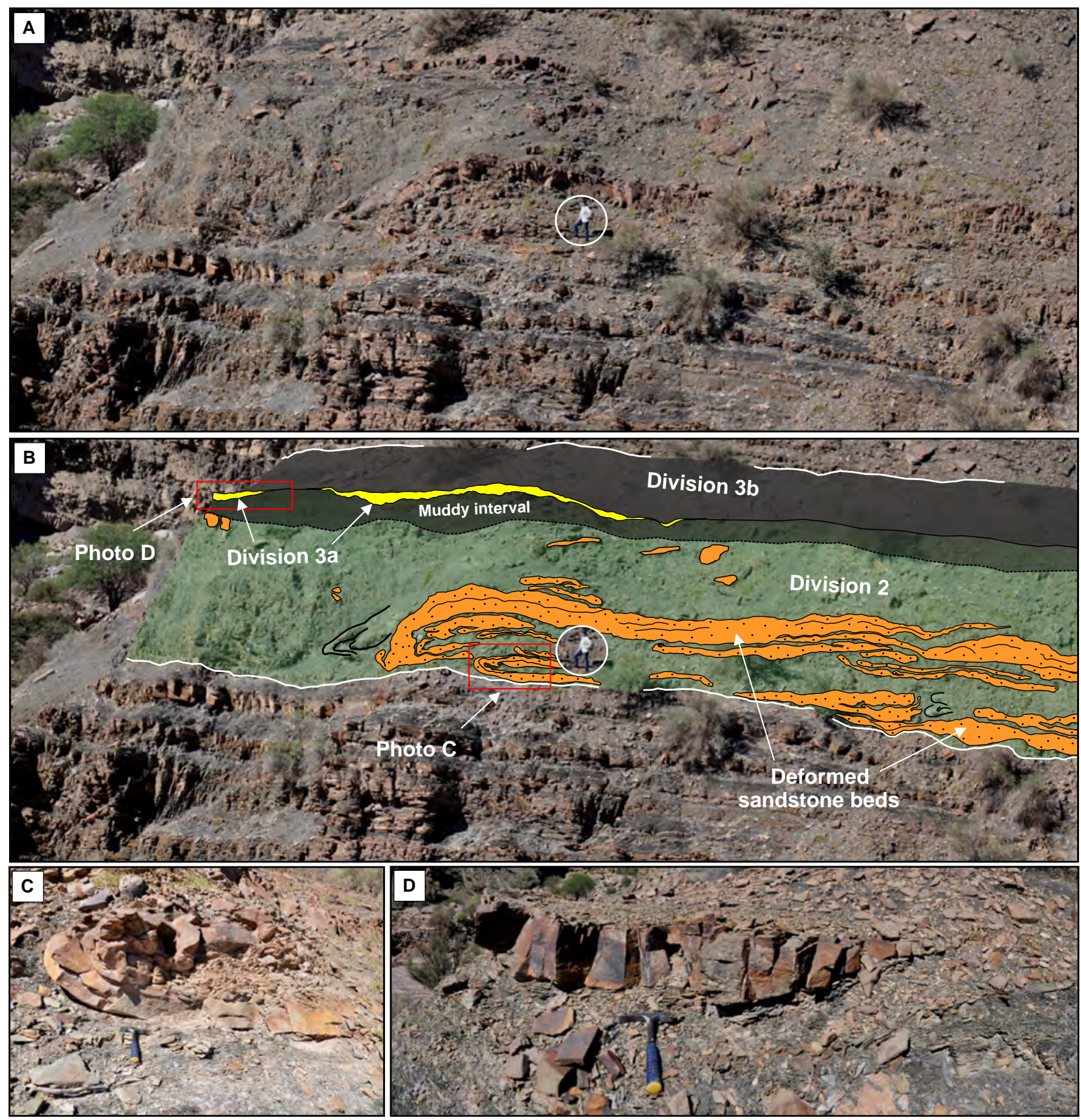

Fig. 11. Slumped unit of Megabed III. (A) Outcrop at South Valley (circled person for scale, ca $1.8 \mathrm{~m}$ tall). (B) Line drawing of (A) showing a slumped unit within division 2 and the lack of division 1. Note also a muddy top of division 2. The locations of (C) and (D) are indicated by red boxes. (C) Detailed view of a recumbent folded sandstone bed within the slump unit. Hammer for scale is $30 \mathrm{~cm}$ long. (D) Detail of division 3a partially confined on the top of division 2, forming small-scale lenses of sandstone that abruptly pinch out against division 2 topographic highs.

changes along dip and its length is probably much larger than the $7 \mathrm{~km}$ of its continuous exposure at the Cerro Bola.

Megabed IV is structureless and shows a sharp contact with the underlying siltstone and mudstone, and includes a basal $\leq 3 \mathrm{~m}$ thick sandy interval that is entirely massive (division 3a, Fig. 12A). Near the sandstone base it includes clast-supported conglomerates (Fig. 12B) with granules and rare small pebbles 


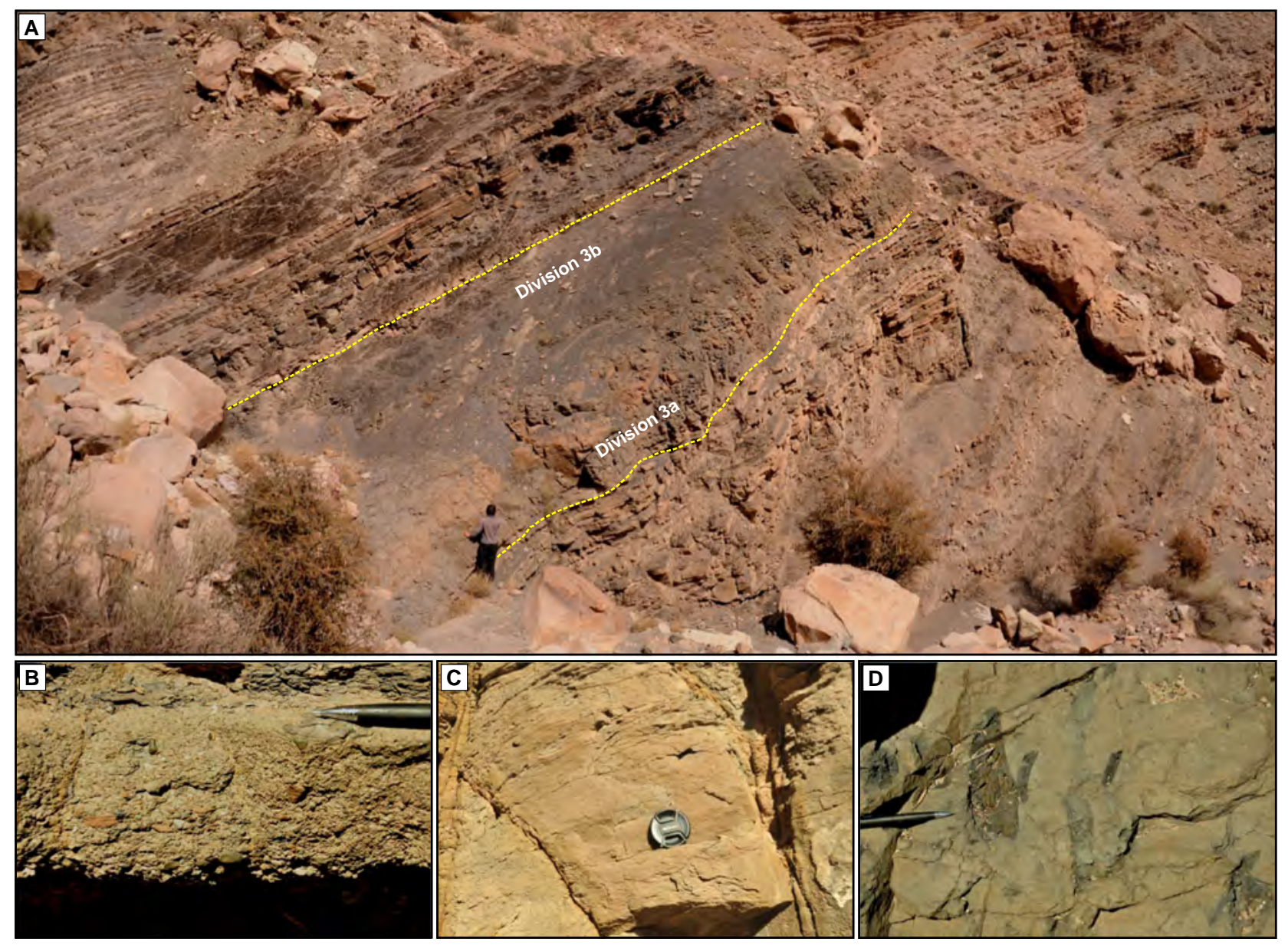

Fig. 12. Main features of the single interval Megabed IV. (A) General view at Cascada de la Muerte section (yellow lines represent base and top of bed). Observe the large thickness of Megabed IV relative to surrounding strata (note a person for scale, ca $1.8 \mathrm{~m}$ tall). (B) Coarse-grained base of the megabed, with granules and rare small pebbles, which grades upward to (C) massive, medium to fine-grained sandstone (top of bed towards top of image) and then to (D) very fine-grained sandstone with mud clast clusters (the photograph is a plan view). This sandy package is capped by siltstones and mudstones derived from suspended load fallout (division 3b, photograph A). Pen is $14 \mathrm{~cm}$ long; lens cap is $7 \mathrm{~cm}$ in diameter.

that grade upward into medium-grained sandstone (Fig. 12C). This medium-grained sandstone is overlain transitionally by fine-grained to very fine- sandstone displaying local mud clast concentrations (Fig. 12D). Mudstone clasts are aligned parallel to bedding, not imbricated and are notably concentrated at the top of the sandstone. This sandstone passes upward into a thick ( $c a 3 \mathrm{~m}$ ) siltstone/mudstone cap of division $3 \mathrm{~b}$.

\section{Depositional mud content}

\section{Textural analysis}

Samples for thin sections were collected from both divisions 2 and 3, which are representative of Megabed III (see Fig. 6 for sampling location).
Each thin section was analysed by 300 point counts, following van der Plas \& Tobi (1965); Neilson \& Brockman (1977) and the approach used by Johnson (1994) to determine statistical distribution of grain size. Grain size was determined by measurements of the long axis diameter of the grains. Longer sectioned flakes of muscovites were excluded from the readings because they could denote a different settling process than those related to the surrounding grains (Talling et al., 2004). The mud content was defined by grains smaller than $32 \mu \mathrm{m}$, and they were also excluded from the mineral composition analysis mainly because optical microscopes do not distinguish grains smaller than this diameter. Because grains do not show dissolution borders, an authigenic origin of the matrix 

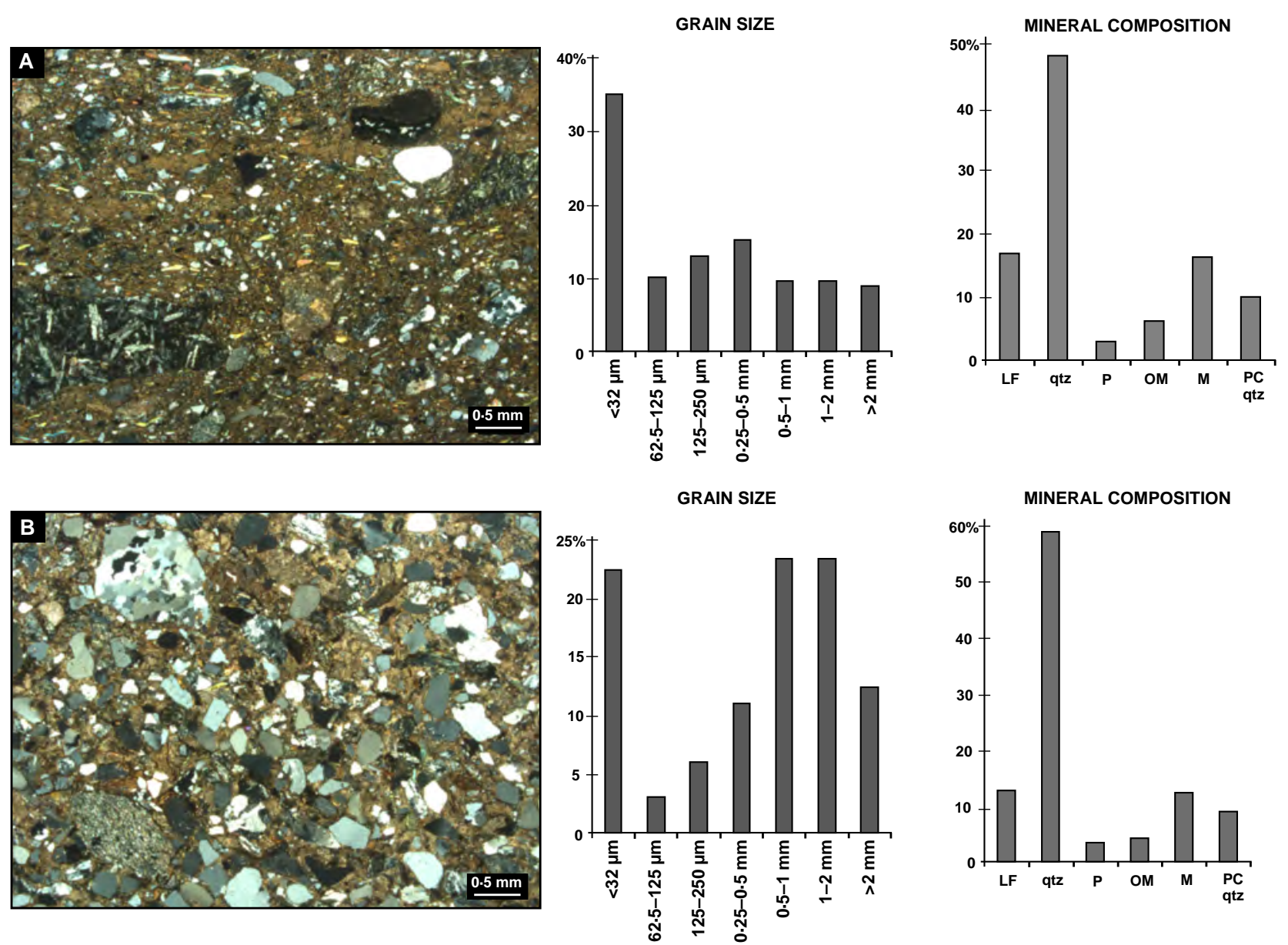

Fig. 13. Textural analysis from thin sections. (A) and (B) representative photomicrographs under cross-polarized light of divisions 2 and 3, respectively, and associated percentages of grain sizes and mineral composition. In both thin sections the mud content was defined by grains smaller than $32 \mu \mathrm{m}$, which constitutes a brownish matrix. Division 2 has more than $34 \%$ mud content while in division 3 it is $>22 \%$. Both divisions have similar mineral composition. $\mathrm{LF}=$ Lithic fragments; qtz = Quartz; $\mathrm{P}=$ Plagioclase; OM = Organic Matter; $\mathrm{M}=\mathrm{Muscovite;} \mathrm{and} \mathrm{PC}$ qtz = Polycrystalline Quartz.

is unlikely, suggesting a detrital provenance. Mud content was thus quantified using the area covered by grain sizes below $32 \mu \mathrm{m}$. Mineral composition, also provided by optical petrography for grains larger than $62.5 \mu \mathrm{m}$, was compared qualitatively and then used to determine whether divisions 2 and 3 originated from the same source.

The sample for the thin section of division 2 was collected in the middle part thereof. Petrographic data from this division show a mudmatrix content of more than $34 \%$ (Fig. 13A), often present as a variety of grain sizes chaotically distributed in a brownish coloured matrix. The percentage of grain sizes larger than $62.5 \mu \mathrm{m}$ remains similar throughout the analysed thin section; they are mainly composed of quartz (47\%), with secondary detrital rock fragments $(16 \%)$ and muscovite $(16 \%)$. The sample collected from division 3 was located near the base of the interval, in a low point over the division 2-related topography. Optical petrography suggests a mud-matrix content of more than $22 \%$ (Fig. 13B). Grains larger than $0.25 \mathrm{~mm}$ are abundant, mainly very coarse and coarse sand (more than 23\% each). Mineral composition in division 3 is very similar to that of division 2, consisting mainly of quartz (58\%), detrital rock fragments $(12 \%)$ and muscovite $(4 \%)$.

\section{Gamma spectrometer signatures}

Gamma-ray results indicate values between 241 and 277 CPS (counts per second) for divisions 1 and 2 of Megabed II (Fig. 7), suggesting 
relatively high mud content of the matrix, as confirmed by petrographic analysis. Potassium ranges from 1.8 to $2 \cdot 7 \%$, uran $\bigcirc$ from 3.0 to $5 \cdot 2 \mathrm{ppm}$ and thorium from 10 o $12.8 \mathrm{ppm}$. The fluctuating values of $\mathrm{K}, \mathrm{U}$ and Th point to a heterogeneous matrix, and probably indicate variations in mud content. High mud content suggests high cohesion and low permeability and primary porosity.

Gamma-ray readings for Megabed III indicate values between 215 and 288 CPS for divisions 1 and 2 (Fig. 7), which also suggest a high mud content. However, the high gamma signature of division 1 may be related to clast compositions, as pebble-size grains dominate the interval. Potassium content ranges from $2 \cdot 0$ to $3 \cdot 7 \%$, but increases upward. Uranium content shows high peaks in the mid portions of division 2 , but in general varies from 1.0 to $6.2 \mathrm{ppm}$. Finally, thorium readings range from 5 to $17 \mathrm{ppm}$, but display an abrupt increase near the top. The sandy portion of division 3 ranges from 230 to 278 CPS, again suggesting dirty sandstones. These readings, however, decrease upward, pointing to a cleaning-upward trend. Potassium ranges from 2 to $4 \%$ and also decreases towards the top. Uranium and thorium show abrupt peaks in the middle parts of the bed, with values ranging from 1 to $6 \mathrm{ppm}$ and 7 to $19 \mathrm{ppm}$, respectively. The mud cap shows high values of CPS with peaks between 300 (base) and 335 (top) and K, $\mathrm{U}$ and Th increasing upward.

The gamma-ray signature for Megabed IV indicates a continuous upward increase in radioactivity (Fig. 7), from 300 to 425 CPS, as expected for a sand to mud deposit (division 3). The relatively high values for sandstones suggest dirty, mud-rich deposits and resulting low permeability due to poor primary porosity. An upward increasing trend for potassium $(2 \cdot 3$ to $5 \cdot 2 \%$ ), uranium ( $4 \cdot 1$ to $15.0 \mathrm{ppm}$ ) and thorium (5.2 to $20 \cdot 3 \mathrm{ppm}$ ) values is also consistent.

\section{DISCUSSION}

\section{Interpretation of the internal divisions}

The megabeds here described comprise up to three broad divisions, interpreted to represent a spectrum of flow properties and rheologies, indicative of a wide range of grain support mechanisms. As stated before, these divisions are part of a generic, idealized facies motif that characterizes the emplacement processes and resulting deposits. Division 1 is not present in outsize megabeds, being more common in those that are relatively thinner. The occurrence of divisions 2 and 3 as defined here is apparently common in megabeds that have been described elsewhere.

\section{Division 1}

Division 1, occurring at the base of Megabeds II and III, represents a notable concentration of pebbles within matrix-supported and clast-supported conglomerates, showing rare, weak normal grading in the upper part. This interval may be interpreted as the result of a precursor (but related) high-density turbidity current (Lowe, 1982) or concentrated density flow, sensu Mulder \& Alexander (2001), perhaps behaving as a gravelly traction carpet. However, the lack of division 1 associated with or close to the slump and its presence further down-dip may suggest that these deposits were formed by dilution of the precursor debris flow (division 2, see below), possibly induced by shearing at its base and resulting ambient water entrainment, or were partially eroded by the succeeding mass debris. Dilution of this basal layer may lead to segregation, differential settling and resulting deposition of clastsupported conglomerates and normally graded sandstone or, with less efficient segregation, matrix-supported conglomerates. In other words, these deposits show evidence that suggests a first stage when dilution took place and the basal layer of the parental debris flow evolved to a less concentrated granular or turbulent flow, the latter responsible for the metre-scale basal scours. Dispersive pressure was probably the main particlesupport mechanism of the basal layer.

An alternative explanation for the origin of division 1 is that the largest clasts present in division 2 may have sunk gravitationally to the bottom of the debris flow, being dragged and sheared as a gravelly traction carpet. Division 2 shows an upward fining of the largest clasts that may be related to this alternative process. An additional but unlikely explanation is that the co-genetic turbidity current (division 3 , see below) may have moved in front of the debris flow, forming a halo around the snout that generated a basal layer that was overridden by the parental debris (Sohn, 2000) although the maximum grain size of division 1 makes this unlikely.

Roughly similar genetically associated basal layers have been described from outcrops (Wood \& Smith, 1957; Sohn, 2000; Talling et al., 2004, 
2012), cores (Talling et al., 2010) and flume experiments (Marr et al., 2001; Sumner et al., 2009). An increase in mud content may induce a change from Newtonian to non-Newtonian (Bingham or Herschel-Bulkley) behaviour during the downflow transition to division 2 (e.g. Manica, 2012). The absence of division 1 in Megabed I may be related to its failure to develop or to reach this part of the basin, its complete erosion by the mass flow (Talling, 2013), or simply because there were not large enough clasts to sink gravitationally from the debris flow.

\section{Division 2}

As mentioned above, the chaotic, ungraded, matrix-supported, pebble conglomerate of division 2 is interpreted to result from debris-flow deposition. Division 2 of megabeds suggests en masse deposition after cohesive freezing. The clay-rich sandy matrix supporting chaotically distributed large protruding clasts and pieces of sandstone beds, as well as cohesive rafts, indicates inefficient sorting and high yield strength. Streaks of sandstones originated by shearing around sandstone blocks in the inferred transport direction may have contributed sand to the debrite matrix (Dykstra et al., 2011; Sobiesiak et al., 2016a). Large blocks of sandstones in Megabed I are interpreted to have been plucked from underlying fluvio-deltaic deposits, resulting in gouges and grooves in the substrate along the basal contact of division 2a (Dykstra et al., 2011; Sobiesiak et al., 2016a) and strongly suggesting the interaction of the flow responsible for division 2 with the underlying deposits. In Megabed III, large blocks of sandstones and slabs of mudstones within the debrite (division 2) do not have affinity with the fragmented and deformed sandstone beds within the basal slump unit, therefore suggesting that they do not have a common origin. Thus, the large rafts within division 2 could be far-travelled from upslope regions, if their densities do not exceed that of the matrix debris (Hampton, 1979; Pierson, 1981; Talling et al., 2010). Alternatively, they could have been plucked from the substrate, probably after the basal layer had been generated, as indicated by scours and erosion over the underlying beds, being ripped up into the debris flow and concentrated near the base. The irregular topography at the top of the debrite is interpreted to be a result of a combination of matrix strength and cohesive freezing.

\section{Division 3}

Division 3 of the megabeds is interpreted as a co-genetic turbidite deposited by a high to lowdensity current (Lowe, 1979, 1982). Normal grading suggests layer by layer deposition from non-cohesive flows. However, the high mud content and gamma readings of this division indicate dirty sandstones, and may signify a transition from the debris flow. Deformational structures in the contact between divisions 2 and 3 suggest dilution and stripping of surface materials by the overriding turbidity current, as well as the incorporation of mud clasts into the overlying deposit. The sudden variation in thickness, the grain-size distributions and the local grain-size breaks within division 3a are interpreted to be the result of partial confinement and interactions of the turbidity current with the debrite-related topography (see further discussion). Scattered palaeocurrent directions at the top of the division 3a in Megabed II suggest interactions of more dilute flows against the irregular topography to produce multiple flow directions; also grain-size breaks could indicate flow reflection (Pickering \& Hiscott, 1985; Kneller et al., 1991). Division 3b is interpreted as mud fallout resulting from the final deceleration and turbulence decay in the residual cloud of the turbidity current. The same interpretation, of a turbidity current, is attributed to division 3 of Megabed IV. However, its structureless and normally graded nature suggests rapid deceleration to form a very thick massive deposit.

\section{Comparison with previous works}

The divisions here described bear comparison with those of megabeds described from elsewhere (Fig. 14). Bourrouilh (1987) interpreted late Cretaceous (Santonian to Maastrichtian) deposits $\leq 18 \mathrm{~m}$ thick in the north Pyrenean basin as the product of a mass flows followed by huge turbidity currents (graded, sand to mud megaturbidite). These beds are replaced in more proximal settings by 10 to $30 \mathrm{~m}$ thick debrites and more distally by turbidites, suggesting a progressive downslope evolution by elutriation of fine material from the mass flow, or conversely progressive entrainment of ambient water, to generate the turbidity current. Bourrouilh (1987) also noted repeated Bouma divisions in the turbidite, and the local presence of symmetrical ripples, invoking rebound of the flow from sea-floor topography. 


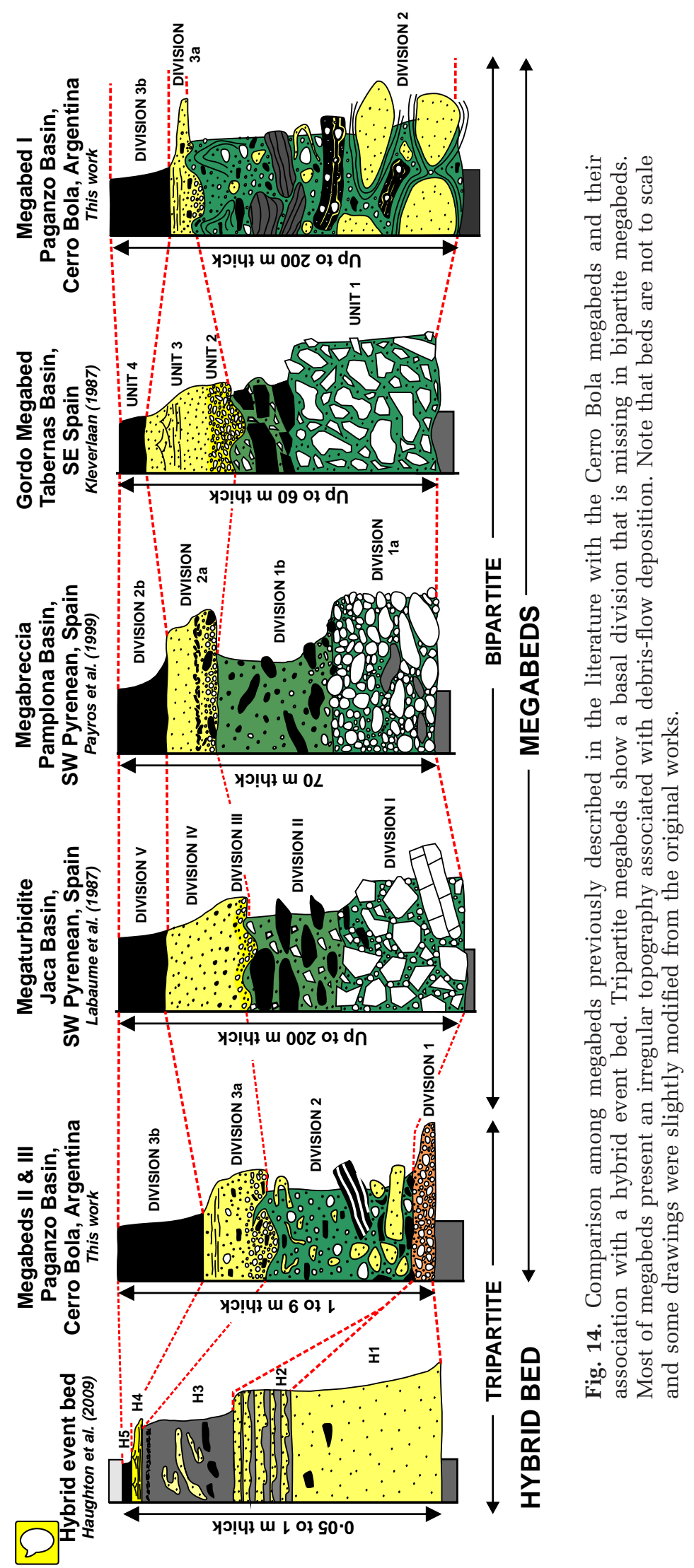


Rupke (1972), Johns et al. (1981), Labaume et al. (1987) and Payros et al. (1999) described comparable, up to $200 \mathrm{~m}$ thick debrite-turbidite couplets in the Eocene (Ypresian to Lutetian) of the southern Pyrenees. Although differing in nomenclature, all of these authors recognized the following internal divisions: largely clastsupported and poorly organized megabreccia; carbonate megabreccia which contains an abundance of intra-basinal rip-up clasts; graded calcirudite with a calcarenite matrix; graded coarse to fine-grained calcarenite with local repetitions of parallel and cross-laminated intervals (Rupke, 1972); and homogeneous marlstone. As in the north Pyrenean examples (Bourrouilh, 1987), the scale of the clasts in the lowermost unit (up to $100 \mathrm{~m}$ thick and several hundreds of metres across) rules out transport by turbidity currents. Thus, two broad divisions can be recognized; an initial clast to matrix-supported mass flow (equivalent to division 2 herein), overlain by a $\leq 20 \mathrm{~m}$ graded package (equivalent to division 3 herein). Payros et al. (1999) recognized a downcurrent change essentially similar to that proposed by Bourrouilh (1987) from proximal chaotic, mud-supported debris-flow breccias, with overlying carbonate turbidite, to more distal, thinner, graded carbonate turbidite lacking the breccia divisions.

Kleverlaan (1987), Haughton (2000) and Hodgson \& Pickering (2008) studied the Late Miocene Gordo Megabed of the Tabernas Basin, southeast Spain, and recognized a similar differentiation onto a lower deposit of a cohesive flow, followed by a graded interval (Units II to IV of Kleverlaan 1987) related to non-cohesive flows. Kleverlaan (1987) reported a grading of the largest clasts within the debrite component (also observed in Megabeds I, II and III), where large blocks are concentrated near the base and less frequent towards the top. Kleverlaan (1987) recognized an interval of clast-supported pebble conglomerate (comparable to that observed by Labaume et al., 1987) deposited over the irregular surface of the basal debrite; this interval, which is missing in the Cerro Bola megabeds, may represent a confinement (or ponding) of the largest clasts at the base of the co-genetic turbidite over the debrite-related topography in the proximal reaches (see later discussion).

Haughton et al. (2009) provide an idealized organization of a typical hybrid event in 1 to $2 \mathrm{~m}$ thick beds (Fig. 14); this classification records longitudinal and/or lateral heterogeneity in flow structure, with changes in flow behaviour from turbulent to transitional and laminar. The ideal hybrid bed of Haughton et al. (2009) shows five stacked divisions (H1 to H5): $\mathrm{H} 1$ corresponds to the deposit of a high-density turbidity current, with its upper part characterized by transitional flow deposits (H2); H3 is interpreted as a mud-rich, cohesive debris-flow interval; H4 constitutes a thin, low-density turbidity current deposit capped by mudstone from suspension fall-out (H5). Compared with the present work, H1 of Haughton et al. (2009) may be equivalent to division 1 herein because it indicates less cohesive or more turbulent conditions near the base of (or preceding) the debris flow; H3 represents division 2 herein, whereas $\mathrm{H} 4$ and $\mathrm{H} 5$ correspond to divisions $3 \mathrm{a}$ and $3 \mathrm{~b}$, respectively. The lack of the H2 (transitional flow) division seems to be a general feature in megabeds, either because the debris flow completely eroded these transitional deposits or outran it due to high mobility (Talling, 2013). Alternatively, the complexity of flow transformations could be manifested in various ways (i.e. Lowe \& Guy, 2000), therefore lacking the specific characteristics of the H2 division of Haughton et al. (2009).

Divisions 2 and 3 proposed here are comparable to the essentially bipartite structure described by Bourrouilh (1987), Labaume et al. (1987), Kleverlaan (1987) and Payros et al. (1999) (Fig. 14), and show several similarities with the Cerro Bola megabeds despite their thicker divisions (mainly a consequence of the large amount of sediment involved in the resedimentation process) and lack of a basal, noncohesive transport phase. Comparison with the Haughton et al. (2009) model shows that these megabeds fit in the broader class of hybrid events. However, the idealized hybrid bed of Haughton et al. (2009) largely represents the transition from turbidity current to debris flow by a process of re-concentration of the initial turbidity current, whereas megabeds described in the literature largely represent the reverse, i.e. an initial debris flow diluted by stripping of surface materials. Megabeds II and III described here may comprise elements of both, including water ingestion, increased shear and a non-cohesive transport phase at the base of the debris flow.

\section{Flow-deposit interactions}

The topography generated at the top of debrites is apparently due to the high yield strength of the debris-flow deposits that results in an irregular surface after cohesive freezing. Shearing at 

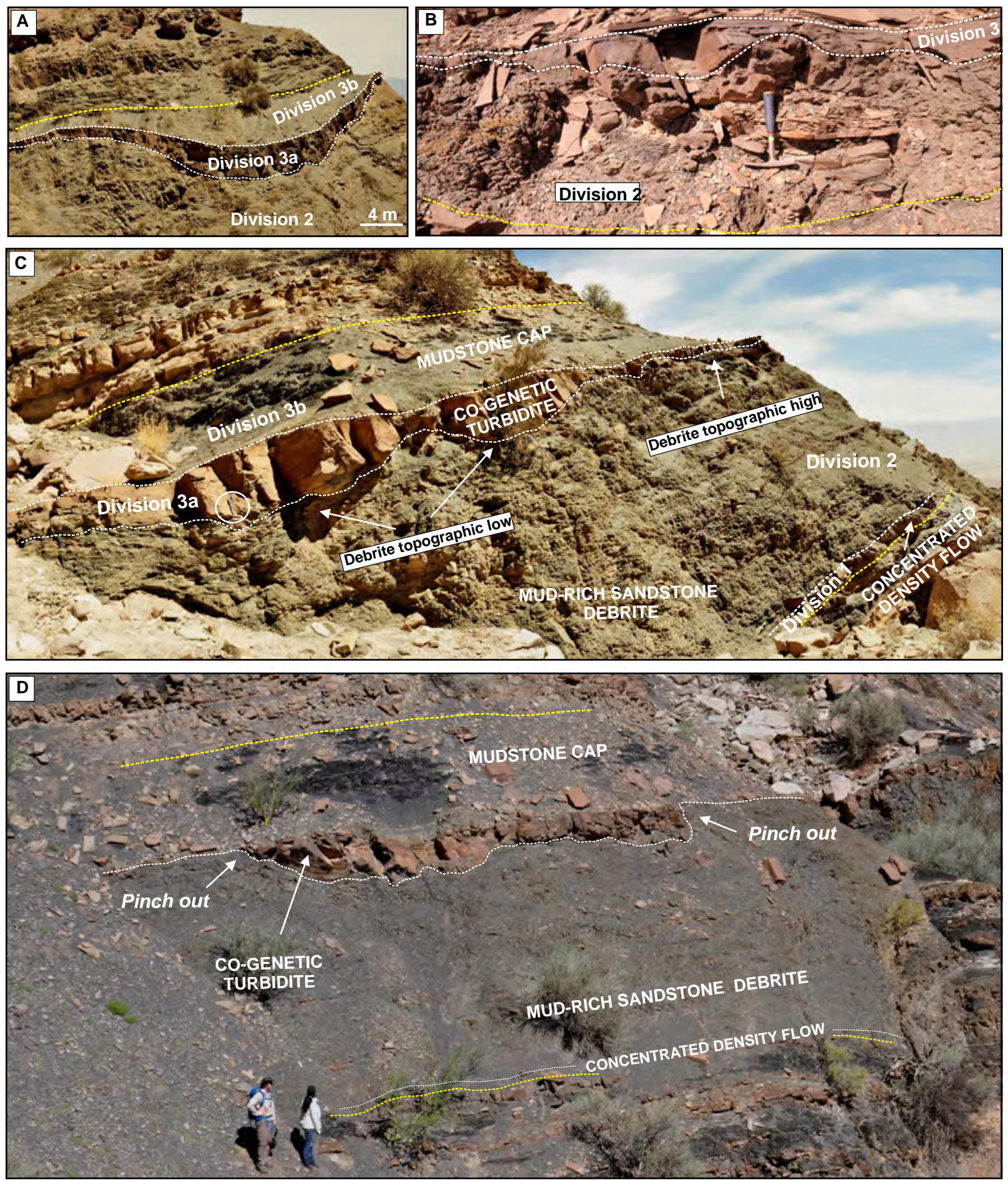

Fig. 15. Detailed view of the interaction between co-genetic turbidites and debrite-related topography. (A) Cogenetic turbidite linked to a very large debrite (MTD II); the deformation of the turbidite bed is produced by subsequent differential compaction and creep of the MTD (dashed white line = internal division; dashed yellow line = top of bed). (B) Megabed I shows that even in low volume debrite an irregular upper morphology is generated and partially confines the thin co-genetic turbidite (dashed yellow line = base of bed; dashed white line = internal division). (C) and (D) Examples of co-genetic turbidite confined by debrite-related topography, forming deposits that pinch out (or thin out) over topographic highs. Both examples are from Megabed III and their internal organization is also shown [(C) is a close-up of Fig. 9A]. Circled hammer for scale in (C). Dashed yellow lines = base and top of bed; dashed white lines = megabed internal divisions. 
the top of the debris flow may lead not only to erosion but also to deformation of its upper surface (Felix et al., 2009). Low strength debrites may not form significant relief because they tend to be too weak to maintain the topography. The interpretation of an upper, genetically associated turbidity current for the Cerro Bola megabeds implies that the debrite topography was generated contemporaneously with or immediately prior to the turbidite deposition. This irregular surface of the debrite in turn controls the distribution of sand by 'ponding' or partially confining later flows. Although complete ponding can only be provided by three-dimensional (3D) topography, 2D features suggest that the co-genetic turbidite of Megabed I could be fully trapped by the debrite-related topography, as opposed to Megabeds II and III in which a partial confinement is more likely. For the case of Megabed I, the resultant topography is greater than the thickness of the sand component of the co-genetic turbidite, perhaps denoting that it is fully ponded over the mass-transport deposits (MTD) (Fig. 15A). Also, the thick mud cap could indicate a situation where the Megabed I co-genetic turbidite is fully ponded, as the residual cloud is not free to spread and the topography generated was apparently high enough to contain the suspended mud.

The debrites associated with Megabeds II and III show a substantial topography on their upper surface (Fig. 15B to D), producing large-scale depressions (long wavelength and amplitude) superimposed by smaller scale lows and highs (short wavelength and amplitude). For Megabeds II and III, the debrite topographic lows are filled by turbidite deposits, and highs are either marked by a thinner layer or by non-deposition (Fig. 15C and D), generating thin-out and pinchout relations against topographic highs. This implies that the topographic lows captured and partially confined the ensuing turbidity current, mainly the coarse fraction. This effect produces abrupt longitudinal changes (and maybe also lateral) in the subsequent co-genetic turbidite bed geometry, resulting in sudden thickness variation (for example, from 0 to $1 \mathrm{~m}$ ). The spill of sediments (sand fraction) contained in the topographic lows suggests partial confinement of the flow rather than fully ponded. The response of the flows to the topography will depend on the length scale of the flow stratification compared to the height of the topography (Kneller \& McCaffrey, 1995; Kneller \& Buckee, 2000), and in fact the thickness of the flows was probably many times greater than the magnitude of the topographic relief.

In Megabed III, the debrite-related topography also controls the bulk grain-size distribution, with larger grains concentrated close to the lowest points. This topography may induce changes in flow velocity (Kneller, 1995; Kneller \& McCaffrey, 1995), and thus flow competence, resulting in preferential settling of larger pebble-size grains in the negative relief. Where the lows are deepest, grain-size breaks are observed in the co-genetic turbidite and may be a result of these complex interactions of the flow against the irregular topography (Pickering \& Hiscott, 1985). Kleverlaan (1987) and Hodgson \& Pickering (2008) describe an interval of clast-supported, pebbly conglomerates trapped in an irregular debrite top surface (figs 7 and 8, respectively), analogous to the trapping of the coarser grained sediments in the scours (e.g. Kuenen, 1957; Eggenhuisen et al., 2010; Groenenberg et al., 2010). Thus, the flow character may be modified downstream as larger grains are progressively removed from the flow and trapped in the upstream lows. In 2D view, the Megabed III cogenetic turbidite comprises lenses with amplitude of $c a 1 \mathrm{~m}$ and tens of metres of wavelength.

\section{Depositional scenario}

The Cerro Bola megabeds occur in a geological setting that records deposition related to retreating glaciers during glacio-eustatic transgressive to highstand stages. Repeated collapses of the basin margin slope deposits remobilized and resedimented the material into deeper marine settings. This process is recorded in several, largescale mass movements (MTDs, Fig. 1) and at least three smaller scale megabeds deposited during a single transgressive phase.

Megabed I was emplaced during a transgressive phase and re-deposition must have occurred after a significant period of primary accumulation to account for its large volume. The protolith was subsequently remobilized downslope towards the WNW (Dykstra et al., 2011; Kneller et al., 2016). The presence of dropstones within the debris implies the presence of floating ice derived from tidewater glaciers during deposition of the protolith (Valdez et al., 2015). These deposits consist of granule to boulder size clasts of granitoids and metamorphic basement rocks in a silt to mud background, and form the ice-rafted debris, or aquatill protolith (Schermerhorn, 1966), depo- 


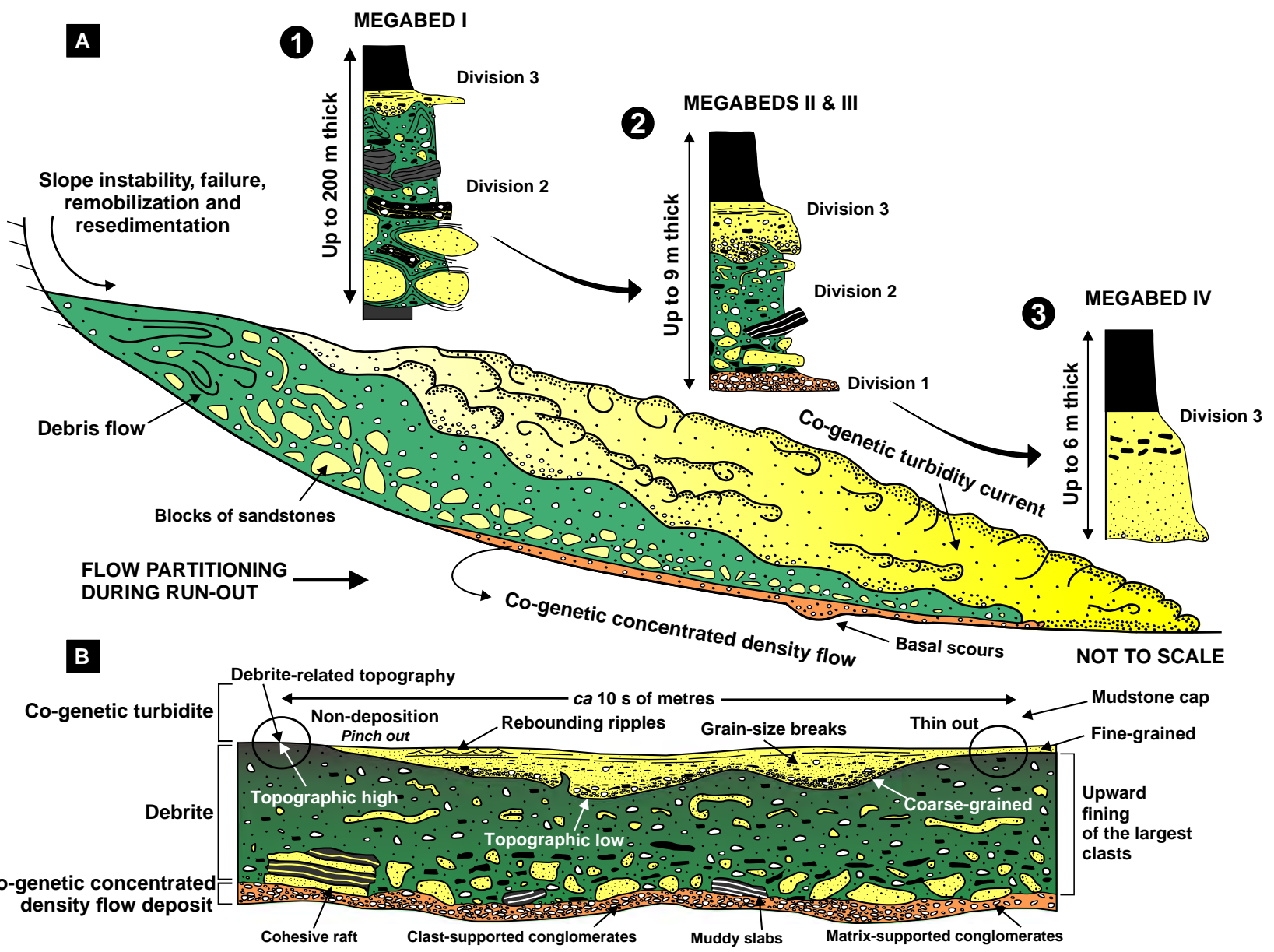

Fig. 16. (A) Generic facies tract model for coarse-grained hybrid megaflows. After protolith resedimentation via mass failure, a debris flow is developed and runs out basinward. Progressive shearing with ambient water leads to generation of co-genetic flows. The debris flow becomes partitioned at the top, generating a co-genetic turbidity current and, at the base, forming a concentrated density flow that behaved as a gravelly traction carpet. This implies that the deposits evolve from a bipartite to a tripartite organization, becoming a simple, more homogeneous flow down the slope, as demonstrated by the upward facies variation (divisions 1 to 3) of the megabeds. Sketch was adapted from Sohn (2000). (B) Idealized longitudinal facies variations within a tripartite megabed (or bipartite megabeds where the basal layer is absent), showing a combination of all typical sedimentary features. Note that the coarser grains of the co-genetic turbidite are trapped in the topographic lows and bed thicknesses may change significantly over the debrite-related topography, generating pinching and thinning out against topograph $\mathrm{P}$ ighs.

sited on the adjacent unstable basin margin, and resedimented via mass failure. For Megabed I, there is ample evidence of the disaggregation of an aquatill protolith to form a debris flow, which probably generated a turbidity current by elutriation or mixing (Mohrig \& Marr, 2003; Felix \& Peakall, 2006). Part of the accommodation under which Megabed I was deposited can only have been created by relative sea-level rise following deposition of the underlying (lowstand) fluvio-deltaic deposits, implying deglaciation and warming climate. Under these conditions, glacier fronts start to calve and disintegrate into icebergs that drift away from the glacier front to release their charge as the ice melts. However, the maximum estimated magnitude of glacioeustatic sea-level changes in the late Mississippian to early Pennsylvanian is only 100 m (Rygel et al., 2008), which implies that tectonic subsidence was also involved and that there was a significant time gap between deposition of Fluvio-Deltaic II and Megabed I.

For Megabeds II, III and IV it is suggested that submarine landslides generated a series of small-scale debris flows, similar to those related to large-scale landslides but under conditions of lower sediment supply, when sea-level was close to its highest position. This idea is 
supported by the stratigraphic position of the megabeds within the flooding zone, and by the lack of dropstones within the debris or in the subjacent and suprajacent sediments. Wood fragments yithin the debrite may indicate vegetal esta- $D$

blishment at the basin margins and thus warmer climatic conditions during protolith deposition, suggesting that the environments could have been completely de-glacial at this time. Clast imbrication within Megabeds II and III and the slumped unit present to the south indicates derivation from the south-eastern basin margin, similar to MTD II (division 2 of Megabed I), which was apparently derived from the ESE. Taking into account that the debrite interval of Megabed IV is present only in the Sierra de Maz inlier (the opposite margin to the source of Megabed III), it is likely that sediment transport related to this megabed was towards the southeast, therefore implying that some megabeds were triggered from opposite basin margins.

\section{Facies tract model and summary of emplacement processes}

Based on similar emplacement processes and similar deposit architecture through several orders of magnitude, a generic facies tract model for coarse-grained megaflows is postulated in Fig. 16A. The vertical facies trend of each megabed is used to infer the longitudinal flow evolution. The final deposits may present some internal variations, as illustrated in Fig. 16B. The heterogeneities are mainly linked to the upper co-genetic turbidite, which is a consequence of how much topography is created over the debris flow upper surface. Under this scenario, a mass failure of protolith generates a downslope movement initially consisting solely of debris flow or by a precursor, genetically related concentrated density flow. During run-out, the debris flow becomes partitioned at the top and maybe at the base, and is overtaken further down the slope by the upper current. This implies that the flow evolves from an initial bipartite structure, passing through a complex tripartite organization, and basinward to a single and simplified arrangement (Fig. 16).

The upper, co-genetic turbidity current is virtually ubiquitous over the slumped deposits, suggesting their generation shortly after mass failure. The co-genetic turbidity current may have been generated by admixing of water along the debris-flow upper boundary (Mohrig \& Marr,
2003) where it may have been more dilute (and weaker) due to stripping of surface materials (Hampton, 1972), and shearing with surrounding water that leads to erosion. Alternatively, the turbidity current may have been generated by dilution of the tail of the debris flow or even by complete disaggregation of a different portion of the initial failure (Felix \& Peakall, 2006). Subsequent compaction and/or creep forms negative and positive relief on the upper surface (Kneller et al., 2016). The co-genetic turbidity current then deposits preferentially along topographic lows to form a bipartite megabed (for example, Megabed I). A 2D view indicates that the geometry of the co-genetic turbidite bed is marked by abrupt lateral thickness changes over the underlying topography.

The continuous run-out and shearing with surrounding water of the debris flow may lead to another partitioning at its base (Fig. 16). For most of the fine-grained hybrid events described in the literature it is hard to determine unequivecally whether the flow responsible for the basal layer (H1 of Haughton et al., 2009), whatever its nature, was formed by dilution of an initial debris flow or if the debris flow was formed by collapse and re-concentration of a precursor turbidity current (Fisher, 1983; Vrolijk \& Southard, 1997; Haughton et al., 2003; Kneller \& McCaffrey, 2003; Waltham, 2004; Talling et al., 2007). However, for thicker and coarser hybrid events (megaflows) it seems that the former hypothesis is the case. For Megabeds II and III, it is suggested that a concentrated density flow (division 1) developed at the base from the initial debris flow during its downslope movement. This is suggested mainly because division 1 is absent where the slump unit is present the case of Megabeds I and III), pointing to its formation further down the slope. This flow transformation may indicate that surrounding water interacts with the base of the debris flow, possibly triggered by an initial hydroplaning process (Bourrouilh, 1987; Mohrig et al., 1998), and was enough to partially dilute the initial debris and segregate the largest clasts to form a flow with vertically varying rheological properties.

Basinward the debris flow freezes en masse, and the upper, more mobile, co-genetic turbidity current may outrun the debris-flow deposit to produce a single thick graded turbidite bed further down-dip (for example, Megabed IV). Mudstone clasts are transported at the rear of the current so that layer by layer deposition concentrates them notably at the tops of sandstone 
beds. This outrunning process is recorded in Megabed IV by a bipartite bed (debrite and turbidite) in the nearby Sierra de Maz area (closer to the source) that is replaced in the Cerro Bola area by a single turbidite bed, in a similar way to what has been observed or postulated elsewhere (Bourrouilh, 1987; Payros et al., 1999).

\section{CONCLUSIONS}

This outcrop-based study of Carboniferous strata from the Cerro Bola area has implications for several aspects of coarse-grained hybrid flows, especially those related to the formation of megabeds. In general, megabeds are represented by high yield strength debrites (division 2) with linked turbidites (division 3), but they also can be associated with a basal, non-cohesive (or partly cohesive) layer (division 1). These divisions constitute a sort of general facies motif, individual components of which may be absent, and which represents a broad spectrum of grain support mechanisms. The sedimentological features described for each megabed suggest similar flow proprieties for both large and small volume events, indicating no significant differences in behaviour despite large differences in the volumes of the initial failure. As a consequence, similar deposit architecture can occur over a couple of orders of magnitude. The similarity between megabeds across a range of scales is therefore probably not coincidental.

The possibility in this study of correlating a megabed to its slump-derived source, which is impossible in most cases, suggests that the debris flow became partitioned during its run-out phase, generating a co-genetic turbidity current at the top and also a concentrated density flow at its base, that may act as a gravelly carpet traction. The partitioning of the debris flow into cogenetic flows may have occurred by shearing on both its upper and lower surfaces. Topographic relief on the upper surface of the debrites was generated contemporaneously with its emplacement and shortly after its elutriation and mixing with surrounding water to form the ensuing turbulent cloud. This topography partly determined the geometry and spatial grain-size distribution of the subsequent co-genetic turbidity current. Sufficient topography is present within smallsize debrites to cause a flow deflection or reflection recorded as rebounding ripples with multiple directions. The overlying co-genetic turbidite has high depositional mud content (dirty sandstones), as suggested by high gammaray readings and indicated by petrographic analyses. Further downstream, the turbidity current may outrun the debris-flow deposit to form a thick, normally graded bed composed of medium to very fine-grained sandstone capped by silt and mud derived from suspension fallout.

\section{ACKNOWLEDGEMENTS}

This research was funded by BG Brasil E\&P Ltda. We thank ANP (National Petroleum Agency of Brazil), Universidade do Vale do Rio dos Sinos (Brazil) and University of Aberdeen (UK). We thank the Associate Editor Peter Talling and the reviewers David Hodgson and Dominic Armitage. We are also indebted with the geologists Victoria Valdez, Matheus Sobiesiak, Carla P. Negre, João Suss, Luke Fairweather and Deise Silveira for their help during many field campaigns. We are also grateful to the Villa Unión and Guandacol communities for their support during several unpredictable situations.

\section{REFERENCES}

Armitage, D.A., Romans, B.W., Covault, J.A. and Graham, S.A. (2009) The influence of mass-transport-deposit surface topography on the evolution of turbidite architecture: The Sierra Contreras, Tres Pasos Formation (Cretaceous), southern Chile. J. Sed. Res., 79, 287-301.

Azcuy, C. L., Carrizo, H. A. and Caminos, R. (1999) Carbonífero y Pérmico de las Sierras Pampeanas, Famatima, Precordillera, Cordillera Frontal y Bloque de San Rafael. In: Geologia Argentina (Ed. Caminos, R.), vol. 29, pp. 261-318. Instituto de Geología y Recursos Minerales, Buenos Aires.

Bouma, A.H. (1987) Megaturbidite: An acceptable term? GeoMar. Lett., 7, 63-67.

Bourrouilh, R. (1987) Evolutionary mass flow-megaturbidites in an interplate basin: Example of the North Pyrenean Basin. Geo-Mar. Lett., 7, 69-81.

Brunt, R.L., McCaffrey, W.D. and Kneller, B.C. (2004) Experimental modeling of the spatial distribution of grain size developed in a fill-and-spill mini-basin setting. J. Sed. Res., 74, 438-446.

Cita, M.B., Beghi, C., Camerlenghi, A., Kastens, K.A., McCoy, F.W., Nosetto, A., Parisi, E., Scolari, F. and Tomadin, L. (1984) Turbidites and megaturbidites from The Herodotus Abyssal Plain (eastern Mediterranean) unrelated to seismic events. Mar. Geol., 55, 79-101.

Cronin, B.T., Owen, D., Hartley, A. and Kneller, B.C. (1998) Slumps, debris flows and sandy deep-water channel systems: Implications for the application of sequence stratigraphy to deep water clastic systems. J. Geol. Soc. London, 155, 429-432.

Dykstra, M., Kneller, B. and Milana, J.P. (2006) Deglacial and postglacial sedimentary architecture in a deeply 
incised Palaeovalley-Palaeofjord-The Pennsylvanian (Late Carboniferous) Jejenes Formation, San Juan, Argentina. GSA Bull., 118, 913-937.

Dykstra, M., Garyfalou, K., Kertznus, V., Kneller, B., Milana, J.P., Molinaro, M., Szuman, M. and Thompson, P. (2011) Masstransport deposits: Combining outcrop studies and seismic forward modeling to understand lithofacies distributions, deformation and their seismic expression. In: Mass-Transport Deposits in Deepwater Settings (Eds R.C. Shipp, P. Weimer and H.W. Posamentier), SEPM Spec. Publ., 96, 293-310.

Eggenhuisen, J.T., McAffrey, W.D., Haughton, P.T.W. and Butler, R.W.H. (2010) Small-scale spatial variability in turbidity-current flow controlled by roughness resulting from substrate erosion: field evidence for a feedback mechanism. J. Sed. Res., 80, 129-136.

Felix, M. and Peakall, J. (2006) Transformation of debris flows into turbidity currents: mechanisms inferred from laboratory experiments. Sedimentology, 53, 107-123.

Felix, M., Leszczynski, S., Slaczka, A., Uchman, A., Amy, L. and Peakall, L. (2009) Field expressions of the transformation of debris flow into turbidity currents, with examples from the Polish Carpathians and French Maritime Alps. Mar. Petrol. Geol., 26, 2011-2020.

Fernandez Sevesso, F. and Tankard, A.J. (1995) Tectonics and stratigraphy of the late Palaeozoic Paganzo Basin of western Argentina and its regional implications. In: Petroleum Basins of South America (Eds A.J. Tankard, J. Suarez and H.J. Welsink), AAPG Mem., 62, 285-301.

Fisher, R.V. (1983) Flow transformations in sediment gravity flows. Geology, 11, 273-274.

Groenenberg, R.M., Hodgson, D.M., Prélat, A., Luthi, S.M. and Flint, S.S. (2010) Flow-deposit interaction in submarine lobes: insights from outcrop observations and realizations of a process-based numerical model. J. Sed. Res., 80, 252-267.

Hampton, M.A. (1972) The role of subaqueous debris flow in generating turbidity currents. J. Sed. Petrol., 42, 775-793.

Hampton, M.A. (1979) Buoyancy in debris flow. J. Sed. Petrol., 49, 753-758.

Hampton, M.A., Lee, H.J. and Locat, J. (1996) Submarine landslides. Rev. Geoph., 34, 33-59.

Haughton, P. (2000) Evolving turbidite systems on a deforming basin floor, Tabernas, SE Spain. Sedimentology, 47, 497-518.

Haughton, P., Barker, S. and McCaffrey, W. (2003) 'Linked' debrites in sand-rich turbidite systems - origin and significance. Sedimentology, 50, 459-482.

Haughton, P., Davis, C., McCaffrey, W. and Barker, S. (2009) Hybrid sediment gravity flow deposits - classification, origin and significance. Mar. Petrol. Geol., 26, 1900-1918.

Hodgson, D.M. (2009) Distribution and origin of hybrid beds in sand-rich submarine fans of the Tanqua depocentre, Karoo Basin, South Africa. Mar. Petrol. Geol., 26, 1940 1956.

Hodgson, D.M. and Pickering, K.T. (2008) Sill-and-fill deepmarine stratigraphy: confined turbidites deposition in the Tabernas-Sorbas basin, Spain. In: Atlas of Deepwater Reservoirs (Eds T. Nielsen, G. Steffens and J. Studlick), Am. Assoc. of Petr. Geol., Tulsa. 1-11.

Jackson, C. and Johnson, H.D. (2009) Sustained turbidity currents and their interaction with debrite-related topography; Labuan Island, offshore NW Borneo, Malaysia. Sed. Geol., 219, 77-96.

Jackson, C., Zakaria, A.A., Johnson, H.D., Tongkul, F. and Crevello, P.D. (2009) Sedimentology, stratigraphic occurrence and origin of linked debrites in West Crocker Formation (Oligo-Miocene), Sabah, NW Borneo. Mar. Petrol. Geol., 26, 1957-1973.

Johns, D.R., Mutti, E., Rosell, J. and Seguret, M. (1981) Origin of thick, redeposited carbonate bed in Eocene turbidites of the Hecho Group, south-central Pyrenees, Spain. Geology, 9, 161-164.

Johnson, M.R. (1994) Thin sections grain size analysis revisited. Sedimentology, 41, 985-999.

Kane, I.A. and Pontén, A.S.M. (2012) Submarine transitional flow deposits in the Paleogene Gulf of Mexico. Geology, 40, 1119-1122.

Kleverlaan, K. (1987) Gordo Megabed: a possible seismite in a Tortonian submarine fan, Tabernas Basin, Province Almeria, southeast Spain. Sed. Geol., 51, 165-180.

Kneller, B. (1995) Beyond the turbidite paradigm: physical models for deposition of turbidites and their implication for reservoir prediction. In: Characterization of Deep Marine Clastic Systems (Eds A.J. Hartley and D.J. Prossers), Geol. Soc. Spec. Publ., 94, 31-49.

Kneller, B.C. and Buckee, C.M. (2000) The structure and fluid mechanics of turbidity currents: a review of some recent studies and their geological implications. Sedimentology, 47, 62-94.

Kneller, B.C. and McCaffrey, W.D. (1995) Modelling the effects of salt-induced topography on deposition from turbidity currents. In: Salt, Sediment and Hydrocarbons (Eds C.J. Travis, H. Harrison, M.R. Hudeac, B.C. Vendeville, F.J. Peel and R.F. Perkins), pp. 137-145. SEPM Gulf Coast Section, Houston, TX.

Kneller, B.C. and McCaffrey, W.D. (2003) The interpretation of vertical sequences in turbidite beds: the influence of longitudinal flow structure. J. Sed. Res., 73, 706-713.

Kneller, B.C., Edwards, D.A., McCaffrey, W.D. and Moore, R.M. (1991) Oblique reflection of turbidity currents. Geology, 19, 250-252.

Kneller, B., Milana, J. P., Buckee, C. and al Ja'aidi, O. (2004) A depositional record of deglaciation in a paleofjord (Late Carboniferous [Pennsylvanian] of San Juan Province, Argentina): the role of catastrophic sedimentation. Geol. Soc. Am. Bull., 116, 348-367.

Kneller, B., Dykstra, M., Fairweather, L. and Milana, J.P. (2016) Mass-transport and slope accommodation: implications for turbidite sandstone reservoirs. Am. Assoc. Petrol. Geol. Bull., 100(2), 213-235.

Kuenen, PhH (1957) Sole markings of graded graywacke beds. J. Geol., 65(3), 231-258.

Labaume, P., Mutti, E. and Seguret, M. (1987) Megaturbidites - a depositional model from the Eocene of the SWPyrenean foreland basin, Spain. Geo-Mar. Lett., 7, 91-101.

Lamb, M.P., Hickson, T., Marr, J.G., Sheets, B., Paola, C. and Parker, G. (2004) Surging versus continuous turbidity currents: flow dynamics and deposits in an experimental intraslope basin. J. Sed. Res., 74, 148-155.

Lamb, M.P., Toniolo, H. and Parker, G. (2006) Trapping of sustained turbidity currents by intraslope minibasins. Sedimentology, 53, 147-160.

Limarino, C.O. and Spalletti, L.A. (2006) Palaeogeography of the upper Palaeozoic basins of southern South America: an overview. J. S. Am. Earth Sci., 22, 134-155.

Limarino, C.O., Césari, S.N., Net, L.I., Marenssi, S.A., Gutierrez, R.P. and Tripaldi, A. (2002) The Upper Carboniferous postglacial transgression in the Paganzo and Río Blanco basins (northwestern Argentina): facies and stratigraphic significance. J. S. Am. Earth Sci., 15, 445-460. 
Limarino, C.O., Tripaldi, A., Marenssi, S. and Fauqué, L. (2006) Tectonic, sea level and climatic controls on Late Palaeozoic sedimentation in the western basins of Argentina. J. S. Am. Earth Sci., 22, 205-226.

López-Gamundí, O.R., Limarino, C.O. and Césari, S.N. (1992) Late palaeozoic palaeoclimatology of central West Argentina. Palaeogeogr. Palaeoclimatol. Palaeoecol., 91, 305-329.

Lowe, D.R. (1979) Sediment gravity flows: their classification and some problems of application to natural flows and deposits. J. Sed. Petrol., 27, 75-82.

Lowe, D.R. (1982) Sediment gravity flows II: depositional models with special reference to the deposits of high density turbidity currents. J. Sed. Petrol., 52, 279-297.

Lowe, D.R. and Guy, M. (2000) Slurry-flow deposits in the Britannia Formation (Lower Cretaceous), North Sea: a new perspective on the turbidite current and debris flow problem. Sedimentology, 50, 45-80.

Manica, R. (2012) Sediment gravity flows: study based on experimental simulations. In: Hydrodynamics - Natural Water Bodies (Eds H.E. Schulz, A.L.A. Simões and R.L. Lobosco), InTech, Croatia, 263-286.

Marjanac, T. (1996) Deposition of megabeds (megaturbidites) and sea level changes in a proximal part of the EoceneMiocene flysch of central Dalmatia (Croatia). Geology, 24 (6), 543-546.

Marr, J.G., Harff, P.A., Shanmugam, G. and Parker, G. (2001) Experiments on subaqueous sandy gravity flows: the role of clay and water content in flow dynamics and depositional structures. Geol. Soc. Am., 113, 1377-1386.

McCaffrey, W.D. and Kneller, B.C. (2001) Process controls on the development of stratigraphic trap potential on the margins of confined turbidite systems, and aids to reservoir evaluation. Am. Assoc. Petrol. Geol. Bull., 85, 971-988.

Middleton, G. V. and Hampton, M. (1973) Sediment gravity flows: mechanics of flow and deposition. In: Turbidites and Deep Water Sedimentation (Eds G.V. Middleton and A. Bouma), pp. 1-38. SEPM, Los Angeles.

Mohrig, D. and Marr, J.G. (2003) Constraining the efficiency of turbidity current generation from submarine debris flows and slides using laboratory experiments. Mar. Petrol. Geol., 20, 883-899.

Mohrig, D., Whipple, K., Hondzho, M., Ellis, C. and Parker, G. (1998) Hydroplaning of subaqueous debris flows. GSA Bull., 110, 387-394.

Mulder, T. and Alexander, J. (2001) The physical character of sedimentary density currents and their deposits. Sedimentology, 48, 269-299.

Mutti, E., Ricci Lucchi, F., Seguret, M. and Zanzucchi, G. (1984) Seismoturbidites: a new group of resedimented deposits. Mar. Geol., 55, 103-116.

Neilson, M.J. and Brockman, G.F. (1977) The error associated with point-counting. Am. Min., 62, 1238-1244.

Pauley, J.C. (1995) Sandstone megabeds from the Tertiary of the North Sea. In: Characterization of Deep Marine Clastic Systems (Eds A.J. Hartley and D.J. Prosser), vol. 94, pp. 103-114. SEPM Special Publications, London.

Payros, A., Pujalte, V. and Orue-Etxebarria, X. (1999) The South Pyrenean Eocene carbonate megabreccias revisited: new interpretation based on evidence from Pamplona Basin. Sed. Geol., 125, 165-194.

Pickering, K.T. and Corregidor, J. (2005) Mass transport complexes and tectonic control on confined basin-floor submarine fans, Middle Eocene, south Spanish Pyrenees. In:
Submarine Slope Systems: Process and Products (Eds D.M. Hodgson and S.S. Flint), SEPM Spec. Publ., 244, 51-74.

Pickering, K.T. and Hiscott, R.N. (1985) Contained (reflected) turbidity currents from the Middle Ordovician Cloridorme Formation, Quebec, Canada - an alternative to the antidune hypothesis. Sedimentology, 32, 373-394.

Pierson, T.C. (1981) Dominant particle support mechanisms in debris flows at Mt. Thomas, New Zealand, and implications for flow mobility. Sedimentology, 28, 49-60.

Piper, D.J.W., Cochonat, P. and Morrison, M.L. (1999) The sequence of events around the epicentre of the 1929 Grand Banks earthquake: initiation of debris flows and turbidity current inferred from sidescan sonar. Sedimentology, 46, 79-97.

van der Plas, L. and Tobi, A.C. (1965) A chart for judging the reliability of point counting results. Am. J. Sci., 263, 87-90.

Pyles, D.R. and Jennette, D.C. (2009) Geometry and architectural associations of co-genetic debrite-turbidite beds in basin-margin strata, Carboniferous Ross Sandstone (Ireland): applications to reservoirs located on the margins of structurally confined submarine fans. Mar. Petrol. Geol., 26, 1974-1996.

Ramos, V.A. (1988) The tectonics of central Andes; $30^{\circ}-33^{\circ} \mathrm{S}$ latitude. In: Processes in Continental Lithosphere Deformation (Eds S. Clark and D. Burchfield), vol. 218, GSA special paper, pp. 31-54. GSA, Boulder.

Reeder, M.S., Rothwell, R.G. and Stow, D.A.V. (2000) Influence of sea level and basin physiography on emplacement of the late Pleistocene Herodutus Basin Megaturbidite, SE Mediterranean Sea. Mar. Petrol. Geol., 17, 199-218.

Ricci Lucchi, F. and Valmori, E. (1980) Basin-wide turbidites in a Miocene, over-supplied deep-sea plain: a geometrical analysis. Sedimentology, 27, 241-270.

Rothwell, R.G. and Kähler, G. (1998) Low sea-level emplacement of a very large Late Pleistocene 'megaturbidite' in the western Mediterranean Sea. Nature, 392, 377-380.

Rothwell, R.G., Reeder, M.S., Anastasakis, G., Tow, D.A.V., Thomson, J. and Kähler, G. (2000) Low sea-level stand emplacement of megaturbidites in the western and eastern Mediterranean Sea. Sed. Geol., 135, 75-88.

Rupke, N.A. (1972) Sedimentology of very thick calcarenitemarlstone beds in a flysch succession, south-west Pyrenees. Sedimentology, 23, 43-65.

Rygel, M.C., Fielding, C.R., Frank, T.D. and Birgenheier, L.P. (2008) The magnitude of Late Paleozoic glacioeustatic fluctuations: a synthesis. J. Sed. Res., 78, 500-511.

Schermerhorn, L.J.G. (1966) Terminology of mixed coarsefine sediments. Sociedade Mineira de Santiago. Aljustrel, Portugal, 831-835.

Shanmugam, G. (2006) Deep-Water Processes and Facies Models, Implications for Sandstone Petroleum Reservoirs. Elsevier, Amsterdam, 476 pp.

Sobiesiak, M., Kneller, B., Alsop, G.I. and Milana, J.P. (2016a) Inclusion of substrate blocks within a mass transport deposit: A case study from Cerro Bola, Argentina. In: Submarine Mass Movements and their Consequences, Advance in Natural and Technological Hazards Research (Eds G. Lamarche and J. Mountjoy), pp. 487-496. Springer, The Netherlands.

Sobiesiak, M., Kneller, B., Alsop, G.I. and Milana, J.P. (2016b) Internal deformation and kinematic indicators within a tripartite mass transport deposit, NW Argentina. Sed. Geol., doi:10.1016/j.sedgeo.2016.04.006 (in press). 
Sohn, Y.K. (2000) Depositional processes of submarine debris flows in the Miocene fan deltas, Pohang Basin, SE Korea with special reference to flow transformation. J. Sed. Res., 70, 491-503.

Souquet, P., Eschard, R. and Lods, H. (1987) Facies sequence in large-volume debris- and turbidity flow deposits from Pyrenees (Cretaceous, France, Spain). GeoMar. Lett., 7, 83-90.

Sumner, E.J., Talling, P.J. and Amy, L.A. (2009) The deposits of flows transitional between turbidity current and debris flows. Geology, 37, 991-994.

Talling, P.J. (2013) Hybrid submarine flows comprising turbidity current and cohesive debris flow: deposits, theoretical and experimental analyses, and generalized models. Geosphere, 9, 460-488.

Talling, P.J., Amy, L.A., Wynn, R.B., Peakall, J. and Robinson, M. (2004) Beds comprising debrite sandwiched within co-genetic turbidite: origin and widespread occurrence in distal depositional environments. Sedimentology, 51, 163-194.

Talling, P.J., Wynn, R.B., Masson, D.G., Frenz, M., Cronin, B.T., Schiebel, R., Akhmetzhanov, A.M., DallmeierTiessen, S., Benetti, S., Weaver, P.P.E., Georgiopoulou, A., Zühlsdorff, C. and Amy, L.A. (2007) Onset of submarine debris flow deposition far from original giant landslide. Nature, 450, 541-544.

Talling, P.J., Wynn, R.B., Schmmidt, D.N., Rixon, R., Sumner, E. and Amy, L. (2010) How did thin submarine debris flows carry boulder-sized intraclasts for remarkable distances across low gradients to the far reaches of the Mississippi fan? J. Sed. Res., 80, 829-851.

Talling, P.J., Masson, D.G., Sumner, E.J. and Malgesini, G. (2012) Subaquous sediment density flows: depositional processes and deposits types. Sedimentology, 59, 19372003.

Valdez, V.B., Milana, J.P. and Kneller, B. (2015) Megadeslizamientos gravitacionales de la formación Guandacol en Cerro Bola y Sierra de Maz y su relación com la glaciación del Paleozoico tardio, la Rioja, Argentina. Lat. Am. J. Sed. Bas. Anal., 22, 109-133.

Vrolijk, P.J. and Southard, J.B. (1997) Experiments on rapid deposition of sand from high velocity flows. Geosci. Canada, 24, 45-54.

Waltham, D. (2004) Flow transformations in particulate gravity currents. J. Sed. Res., 74, 129-134.

Wood, A. and Smith, A.J. (1957) The sedimentation and sedimentary history of the Aberystwyth Grits (Upper Llandoverian). Q. J. Geol. Soc. London, 114, 163-195.

Zapata, T.R. and Allmendinger, R.W. (1996) Growth stratal records of instantaneous and progressive limb rotation in the Precordillera thrust belt and Bermejo basin, Argentina. Tectonics, 15, 1065-1083.

Manuscript received 12 January 2015; revision accepted 4 July 2016 